\title{
Skipulag fyrirtækja á Íslandi fyrir og eftir hrun
}

\author{
Runólfur Smári Steinpórsson, Anna Marín Pórarinsdóttir og Einar \\ Svansson ${ }^{1}$
}

\begin{abstract}
Ágrip
Viðfangsefni greinarinnar er próun á skipulagi fyrirtækja á Íslandi fyrir og eftir fjármálahrunið árið 2008. Byggt er á rannsóknum í verkefninu Innform á Íslandi, annars vegar frá 2004 til 2007 og hins vegar frá 2010 til 2014. Einnig er gerður samanburður á milli fimm rannsókna sem gerðar hafa verið um skipulag fyrirtækja á Íslandi á árunum fyrir og eftir hrun. Markmið greinarinnar er að lýsa megineinkennum á stjórnskipulagi íslenskra fyrirtækja og gera grein fyrir próun á skipulagi peirra. Jafnframt er markmiðið að kanna hvort sjá megi breytingar á skipulagi íslenskra fyrirtækja eftir efnahagshrunið 2008 á ýmsum stjórnunarpáttum sem tengjast skipulagi. Helstu niðurstöður gefa vísbendingar um að stjórnskipulag íslenskra fyrirtækja hafi tekið nokkrum breytingum og að áhersla á innri ferla og skilvirkni sé meiri. Umboðsveiting hefur aukist og sú breyting tengist aukningu á fléttu- og verkefnaskipulagi. Rannsóknirnar sýna að flest stór íslensk fyrirtæki notast bæði við afurðaskipulag og starfaskipulag, sem gefur vísbendingu um blandað skipulag. Starfaskipulag er hins vegar ríkjandi skipulagsform pegar litið er til bæði smærri og stærri fyrirtækja. •að virðist hafa verið millibilsástand hjá fyrirtækjum á Íslandi varðandi stjórnskipulag fyrst eftir hrun par sem áhersla æðstu stjórnenda á formlegt skipulag minnkaði tímabundið.
\end{abstract}

\begin{abstract}
This paper discusses the development of organizational structure in Icelandic enterprises before and after the economic crash in 2008. This is built on data compiled in the Innform research project in Iceland, first from the pre-crash years 2004 to 2007 and second the post-crash years 2010 to 2014. A comparison is also drawn up with an overview of the five published research results about the structure of Icelandic companies in the period of 2004-2016. The purpose of this article is to describe the main characteristics of the organizational structure of Icelandic companies and their evolution. At the same time the aim is to look for changes after the economic crash in 2008 on different management practices related to organizational structure. The main findings point to the direction that organizational structure has partly changed. Especially with more focus on effectiveness and internal processes. Empowerment has increased with correlation to matrix structure and project structure which are increasingly in use. Previous research shows that most big Icelandic companies are using both functional and divisional structure, that relates
\end{abstract}

1 Runólfur Smári Steinpórsson er prófessor í stjórnun og stefnumótun við Viðskiptafræðideild Háskóla Íslands. Netfang: rsmari@hi.is. Anna Marín Pórarinsdóttir er doktorsnemi við Viðskiptafræðideild Háskóla Íslands. Einar Svansson er lektor við Háskólann á Bifröst.

This work is licensed under a Creative Commons Attribution 4.0 License.

DOI: https://doi.org/10.24122/tve.a.2018.15.1.5

(C) Tímarit um viðskipti og efnahagsmál

www.efnahagsmal.is 
to a mixed structure. The functional structure is the overarching form in both the smaller and bigger companies. It looks like a flux period in the structure in the first years after the crash, where the focus of the directors on formal structure dwindled temporarily.

JEL flokkun: M1, L2

Lykilorð: Skipurit; afurðaskipulag; starfaskipulag; fléttuskipulag.

Keywords: Organizational charts; divisional structure; functional structure; matrix structure.

\section{Organizational structure in Icelandic companies before and after the financial crisis.}

\section{Inngangur}

Рað er óumdeilt að stjórnskipulag er fyrirtækjum og stofnunum ákaflega mikilvægt. Ekki síst pegar um viðamikla eða flókna starfsemi er að ræða. Án góðs stjórnskipulags er mikil hætta á mistökum innan skipulagsheilda par sem yfirsýn og samræmingu vantar. Hættan getur falist í pví að nauðsynleg verkefni verði hvorki skilgreind né unnin. Við pær aðstæður par sem stjórnskipulagi er ábótavant er líklegt að skipulagsheildir verði innri óreiðu að bráð.

Ofangreint er lýsandi fyrir hagnýtt mikilvægi stjórnskipulags fyrirtækja og stofnana og pað er í góðu samræmi við ábendingar lykilheimilda um skipulag og skipulagsheildir (March og Simon, 1958; Thompson, 1967; Galbraith, 1977; Child, 1984, 2005; Daft, 1992; Mintzberg, 1979, 1993; Nadler og Tushman, 1997; Jones, 2001). Prátt fyrir mikilvægið er athyglisvert að stjórnskipulag virðist vera vanrannsakað fyrirbæri. Helstu heimildir um stjórnskipulag fyrirtækja og stofnana eru orðnar gamlar og pær er oft að finna í bókum frekar en tímaritsgreinum (Král og Králova, 2016). Algengt er að fjallað sé um stjórnskipulag sem undirpátt í ritverkum sem eru að taka fyrir mikilvæga pætti í árangursríkum rekstri fyrirtækja og stofnana (Worren, 2012; Johnson o.fl., 2014). Раð ritverk sem enn fær einna flestar tilvísanir í rannsóknum tengdar skipulagi er um 50 ára gamalt, p.e. ritverk Thompsons frá árinu 1967 (Worren, 2012). Aðrar skýringar sem Worren nefnir eru pær að viðskiptaháskólar hafi oft sýnt takmarkaðan áhuga á hinum hagnýta pætti rannsókna og að bæði fræðimenn og leiðandi ráðgjafar hafi talað stjórnskipulag niður, sérstaklega lóðrétt stjórnskipulag og áhersluna á valdbraut, sbr. Hammer (2001) og Peters (2003).

Pað er vel pekkt að huga purfi bæði að lóðréttu og láréttu skipulagi með áherslu á bæði formlega og óformlega pætti (Daft, 1992; Jones, 2001) en leiðandi ráðgjafar eins og Tom Peters hafa lengi verið mjög gagnrýnir á hefðbundið skipulag. Í bókinni Liberation Management lagði Peters t.d. áherslu á nauðsyn pess að vinda ofan af ströngu og vanaföstu skipulagi (Peters, 1992). Rannsóknir benda til pess að fjölbreytni í skipulagi hafi pegar verið farin að aukast um síðustu aldamót (Whittington o.fl., 1999). Með stuttu yfirliti um áskoranir og mikilvægi stjórnskipulags fyrirtækja bendir Worren (2012) á rannsóknir sem staðfesta gildi vandaðs stjórnskipulags (Mintzberg, 1979; Nahm o.fl., 2003). Ein pessara rannsókna, sem var gerð af Nicolaj Foss (2003), tók fyrir danska fyrirtækið Oticon, en pað var um tíma pekkt fyrir nýbreytni sína á stjórnskipulagi. Um pá rannsókn segir Worren (2012, bls. 10) með tilvísun í Foss (2003) að „spaghetti skipulag“ Oticon hefði mögulega virkað ef stjórnendur hefðu vandað betur til verka. Petta dæmi undirstrikar mikilvægi stjórnskipulagsins og sýnir um leið að innleiðing á nýju skipulagi er mikil áskorun og tímafrek.

Pekking á skipulagi fyrirtækja og stofnana er mikilvæg á Íslandi eins og annars staðar í heiminum. Nokkuð hefur verið um rannsóknir á skipulagi hérlendis en ritverk um skipulag fyrirtækja eru ekki mörg. Раð ritverk sem mögulega hefur fengið mestu útbreiðslu, aðallega sem stuðningsrit í háskólakennslu, er bókin Skipulag fyrirtækja (Runólfur Smári 
Steinpórsson, Marteinn P. Arnar og Sigurður A. Jónsson 1995) sem lagði grunn að umfjöllun á íslensku um stjórnskipulag fyrirtækja sem víða er vitnað til í öðrum íslenskum ritverkum og ritgerðum um efnið. Hvað rannsóknir á stjórnskipulagi varðar hér á landi pá hefur viðfangsefnið verið tekið fyrir í nokkrum meistararitgerðum á liðnum árum og oft í tengslum við víðtækari akademískar rannsóknir. •að liggja fyrir fjórar rannsóknir sem hafa verið kynntar á ritrýndum vettvangi frá árinu 2006. Sú fyrsta af peim fjallaði bæði um skipulag og stjórnunaraðferðir (Ingi Rúnar Eðvarðsson, 2006). Í framhaldi af peirri rannsókn var gerð ítarlegri rannsókn á skipulagsformum íslenskra fyrirtækja (Ingi Rúnar Eðvarðsson og Guðmundur Kristján Óskarsson, 2008). Á svipuðum grunni var svo nýlega kynnt priðja rannsóknin sem byggir á spurningalista Inga Rúnars og Guðmundar Óskars (Âsta Dís Óladóttir, Ingi Rúnar Eðvarðsson og Guðmundur Kristjánsson, 2016). Pessar rannsóknir ná nú yfir nokkur ár og pví er áhugavert að rýna nánar í pær og bera saman við aðrar rannsóknir sem gerðar hafa verið hérlendis.

Á svipuðum tíma og rannsóknir Inga Rúnars Eðvarðssonar og samstarfsmanna hans komu fram var rannsóknarverkefnið Innform á Íslandi komið af stað, en markmiðið með pví verkefni var að efla rannsóknir á stjórnskipulagi íslenskra fyrirtækja. Fyrstu Innform niðurstöðurnar voru kynntar á ritrýndum vettvangi árið 2012 par sem greint var frá próun á skipulagi íslenskra fyrirtækja á árunum 2004-2007 (Einar Svansson og Runólfur Smári Steinpórsson, 2012) en áður höfðu verkefnið og niðurstöður verið kynntar á ráðstefnu um rannsóknir í félagsvísindum (Runólfur Smári Steinpórsson, 2008; Einar Svansson, 2008b) og í meistararitgerð (Einar Svansson, 2008a). Innform rannsóknin byggði á spurningalista sem próaður var í viðamiklu erlendu rannsóknarverkefni og niðurstöðurnar um próunina á stjórnskipulagi hérlendis 2004-2007 voru settar fram í samanburði við niðurstöður erlendu Innform rannsóknanna. Í umfjöllun um pessar niðurstöður, árið 2012, var bent á að mikilvægt væri að skoða og ræða niðurstöðurnar í samanburði við aðrar íslenskar rannsóknir. Рað var einnig undirstrikað af höfundum að pað væri bæði mikilvægt og áhugavert að gera frekari rannsóknir á stjórnskipulagi íslenskra fyrirtækja á næstu misserum til að sjá betur hvernig skipulag íslenskra fyrirtækja hafi breyst eftir hrun íslenska fjármálakerfisins árið 2008.

Markmiðið með pessari grein er að fylgja pessu eftir og kynna rannsóknir par sem tekist er á við tvennt, p.e. gera grein fyrir og ræða íslenskar rannsóknir á stjórnskipulagi fyrirtækja og kynna nýja rannsókn sem gerð hefur verið á grunni Innform rannsóknarinnar fyrir árin 2010-2014. Jafnframt er ætlunin að draga saman yfirlit yfir stöðu pekkingar á sviðinu og tengja pað tilteknum fræðilegum straumum og rannsóknum á skipulagi fyrirtækja og skoða íslensku niðurstöðurnar í samhengi við pær áherslur sem komu fram í alpjóðlegu Innform rannsókninni á sínum tíma og pær fræðilegu áherslur sem hafa komið fram síðan. Aðalrannsóknarspurning greinarinnar tekur mið af peim samanburði á íslensku rannsóknunum á stjórnskipulagi fyrirtækja sem settur er fram í greininni. Spurt er: Hvað má af íslenskum rannsóknum og samanburði á peim ráða um helstu einkenni á stjórnskipulagi fyrirtækja á Íslandi fyrir og eftir hrun?

Til að svara pessari spurningu og segja nánar frá pví efni sem byggt er á er greininni stillt upp á eftirfarandi hátt. Að loknum inngangi er kafli sem dregur saman stöðu pekkingar á skipulagi fyrirtækja sem lögð er til grundvallar fyrir umræðuna um niðurstöður greinarinnar en par er vikið að bæði eldri kenningum og nýjum straumum í rannsóknum sem tengjast skipulagi fyrirtækja. Síðan er fjallað um pá aðferðafræði sem stuðst hefur verið við í rannsókninni og við samanburðinn á íslensku rannsóknunum. Einnig er fjallað um framkvæmd Innform rannsóknarinnar fyrir árin 2010-2014. Síðan er greint frá niðurstöðum rannsóknarinnar í tveimur hlutum. Annars vegar er rýnt í pað íslenska efni og pær rannsóknir á stjórnskipulagi íslenskra fyrirtækja sem gerðar hafa verið. Hins vegar er fjallað um framlag rannsóknarinnar fyrir árin 2010-2014 í samhengi við fyrri rannsóknir, sérstaklega rannsóknina sem tók fyrir árin 2004-2007. Að pví loknu er umræðukafli og svo umfjöllun um frekari rannsóknir. 


\section{Kenningar um skipulag fyrirtækja}

Kenningar um skipulagsheildir hafa pýðingarmiklu hlutverki að gegna í nútímapjóðfélagi. Meginástæða pess er sú staðreynd að við lifum í pjóðfélagi verkaskiptingar (Douma og Schreuder, 2013). Kenningarnar varpa ljósi á leiðir til að glíma við hin ýmsu vandamál og áskoranir sem einstaklingar, fyrirtæki og stofnanir standa frammi fyrir pegar markmiðið er að ná sem bestum árangri við skilyrði sem jafnan eru pannig að auðlindir til ráðstöfunar eru takmarkaðar, upplýsingar eru af skornum skammti, óvissa ríkir um framtíðina og hætta er á að tækifærismennska og siðbrestur í athöfnum einstaklinga, fyrirtækja og stofnana geri vart við sig (Douma og Schreuder, 2013). Skipulagsheildir eru megineinkenni í nútímasamfélagi og pað má segja að mannlegt samfélag skilgreini sig með hliðsjón af skipulagsheildum og að kenningarnar varpi ljósi á lykilatriði í lífi og starfi einstaklinga, fyrirtækja og stofnana (McAuley, Duberly og Johnson, 2007; Einar Svansson og Runólfur Smári Steinpórsson, 2012). Meðal pessara lykilatriða eru pættir í skipulagi fyrirtækja og stofnana, p.m.t. stjórnskipulagi peirra.

Uppruna kenninga um stjórnskipulag má að hluta til rekja til hugmynda Adam Smith um leiðir til að auka framleiðni í starfi fyrirtækja og stofnana gegnum aukna verkaskiptingu, sérhæfingu og sjálfvirkni á grundvelli vélvæðingar (Douma og Schreuder, 2013). Pessar hugmyndir lögðu m.a. grunninn að vísindalegri stjórnun Frederick Taylors, klassískri stjórnun sem kennd er við Henry Fayol og að kenningum um regluveldi Max Webers (Graetz og Smith, 2006; Einar Svansson og Runólfur Smári Steinpórsson, 2012) sem saman mynda klassískar kenningar um stjórnun og skipulag fyrirtækja (Volberda, 1999; Pettigrew og Fenton, 2000)

Inntakið er að fyrirtæki og stofnanir purfa að hafa gott skipulag til að geta sinnt hlutverki sínu og aðlagast umhverfinu (Galbraith, 1977; Daft, 1992; Jones, 2001; Runólfur Smári Steinpórsson o.fl., 1995). Skipulagið ásamt stefnu fyrirtækis markar nýtingu auðlinda og fjármagns. Skipulag segir fyrir um verkaskiptingu og sérhæfingu í fyrirtækjum og samræmingu starfseminnar (Jones, 2001). Pessu hefur einnig verið lýst sem sundurgreiningu og samtengingu starfseminnar í takti við umhverfi og aðstæður sem gerir mögulegt að ná aukinni framleiðni og skilvirkni í rekstri (Lawrence og Lorsch, 1967), eftir atvikum með áherslu á vélrænt eða lífrænt skipulag (Burns og Stalker, 1966). Skipulagi má pannig lýsa sem lóðréttu og láréttu tengslaneti sem gerir starfsfólkinu í fyrirtækinu kleift að hafa tiltækar pær upplýsingar sem nauðsynlegar eru fyrir starfsemina. Stjórnskipulagið varpar ljósi á aðgerðir og vinnuferla og dregur fram helstu tengsl og boðleiðir. Valdbraut og formlegum samskiptum sem eru á milli starfsmanna, deilda og stjórnenda er t.d. lýst með stigveldi og stjórnunarspönn (Runólfur Smári Steinpórsson o.fl., 1995). Upplýsingaöflun, upplýsingarúrvinnsla og upplýsingamiðlun eru mikilvæg samræmingartæki í pessu samhengi (Douma og Schreuder, 2013) sem jafnframt kalla á lærdóm innan skipulagsheilda (Yang o.fl., 2004) og stjórnun pekkingar (Darroch, 2005; Zeng o.fl., 2010). Helstu pættir í stjórnskipulagi eru grunnpættir, s.s. stigveldi, starfslýsingar, teymi og hópar, og atferlispættir, s.s. viðmið, reglur, ferlar og eftirlitsáherslur (Child, 2005). Stjórnskipulagi er jafnan lýst í svokölluðu skipuriti sem sýnir lóðrétt og lárétt tengsl milli stjórnunareininga og starfsfólks (Daft, 1992; Runólfur Smári Steinpórsson o.fl., 1995; Child, 2005). Mikilvægi skipulags er pví ótvírætt og stigveldið hefur ennpá mikla pýðingu (Leavitt, 2005). Nýjar áherslur hafa verið að koma fram (Pettigrew og Fenton, 2000) en um leið er varað við pví að láta tímabundnar tískusveiflur í skipulagi og stjórnun hafa of mikil áhrif (Child, 2005). Gott stjórnskipulag er mikilvægt tæki til að auka samkeppnishæfni fyrirtækja og er lykill að framkvæmd og framvindu í starfsemi fyrirtækja (Whittington og Mayer, 2000; Worren, 2012). Margir pættir hafa áhrif á mótun og gerð stjórnskipulags. Par má helst nefna stærð, hlutverk, menningu, starfsumhverfi og tækni (Daft, 1992; Runólfur Smári Steinpórsson o.fl., 1995). Eðli málsins samkvæmt er skipulag stórra og smárra fyrirtækja á margan hátt ólíkt. Fyrirtæki eru talsvert háð efnahagsumhverfi og aðstæðum í samfélagi á hverjum tíma og skipulag peirra tekur ávallt mið af pví. 
Stjórnskipulag fyrirtækja og stofnana getur verið af ólíku tagi. Helstu gerðirnar eru starfaskipulag, afurðaskipulag, svæðaskipulag, blandað skipulag, fléttuskipulag og verkefnamiðað skipulag, en auk pessara gerða er í fræðunum fjallað um netskipulag, sjálfstýrt skipulag og skipulagslausnir sem tengjast útvistun og samstarfi á milli fyrirtækja (Child, 2005; Runólfur Smári Steinpórsson o.fl., 1995). Varðandi próun á skipulagi og samspilinu á milli páttanna sem hafa áhrif á skipulag og atriðanna sem lýsa útfærslu á skipulagi er einkum horft til kenninga Chandlers (1962) um samspilið á milli stefnu og skipulags fyrirtækja, p.m.t. ástæður pess að fyrirtækja færa sig frá starfaskipulagi yfir í afurðaskipulag eftir pví sem viðskiptaeiningum fyrirtækja fjölgar. Pegar svo háttar próast skipulag líka í form sem ná utan um viðskiptaeiningarnar, p.e. eignarhaldsskipulag (e. holding) eða samstæður (Whittington og Meyer, 2000). Hér að neðan er svo fjallað nánar um algengustu skipulagsgerðir:

Starfaskipulag byggist á pví að flokka saman sambærileg störf í deildir. Pessu skipulagi er stundum lýst sem U-formi (Whittington og Meyer, 2000) og pað hentar helst smærri fyrirtækjum með einfalda starfsemi og virkar vel í stöðugu umhverfi. Helstu k ostir pess eru möguleiki á stærðarhagkvæmni, aukinni skilvirkni og sérhæfingu deilda. Stjórnendur eiga auðveldara með аð sinna eftirliti og meta afkastagetu innan deilda með svipaða starfsemi. Gallar skipulagsins eru að fyrirtæki eru oft sein að bregðast við breytingum í starfsumhverfinu og markmið sérhæfðra deilda geta verið sett framar heildarhagsmunum viðkomandi fyrirtækis (Daft, 1992; Runólfur Smári Steinpórsson o.fl., 1995; Jones 2001).

Stærri fyrirtæki með fleiri afurðir notast jafnan við svokallað afurðaskipulag, eða M-form (Whittington og Meyer, 2000) með sjálfstæðum rekstrareiningum sem skapa meiri sveigjanleika til pjóna viðskiptavinum og bregðast við flóknari ytri aðstæðum. Kostir pess eru fókus á tilteknar afurðir, aukin framleiðni í rekstri viðskiptaeininga og tækifæri til aðgreiningar. Fyrirtækið í heild nær einnig að nýta sér kosti breiddarhagkvæmni. Gallar eru minni stærðarhagkvæmni og tvíverknaður pegar starfspættir skarast á milli eininga. Einnig getur verið erfitt að staðla og samræma pætti milli framleiðslulína (Daft, 1992; Runólfur Smári Steinpórsson o.fl., 1995; Jones 2001).

Svæðisskipulag er priðja tegundin og hentar stærri fyrirtækjum. Pví svipar að miklu leyti til afurðaskipulagsins varðandi kosti og galla nema að útgangspunkturinn eru landsvæði, innan sem utan heimalandsins. Kostir eru samræming starfsemi með hliðsjón af aðstæðum á mismunandi svæðum og pörfum ólíkra hópa viðskiptavina. Innan svæða er lögð áhersla á lárétta samræmingu og hver rekstrareining einbeitir sér að framleiðslu afurða og veitingu á staðbundinni pjónustu (Daft, 1992; Runólfur Smári Steinpórsson o.fl., 1995; Jones 2001).

Einnig má nefna blandað skipulag par sem fyrirtæki í vexti byggja samhliða á starfaskiptingu og afurðaskiptingu í starfsemi fyrirtækisins en pó án pess að valdbraut sé látin skarast. Kostir blandaðs skipulags er möguleikinn á að setja meiri fókus á vörupróun og nýsköpun peirra afurða sem skipulagið hverfist um. Раð ýtir undir sveigjanleika og aðlögunarhæfni. Gallar eru aukinn stjórnunarkostnaður og hnökrar í samskiptum á milli starfaskiptra og afurðaskiptra eininga. Blönduðu skipulagi svipar til fléttuskipulags en mikilvægt er að gera greinarmun á pessum gerðum skipulags (Runólfur Smári Steinpórsson o.fl., 1995).

Fléttuskipulag á jafnan við stærri skipulagsheildir og getur auk tengingar við bæði starfa- og afurðaskiptingu próast upp úr verkefnaskipulagi. Megineinkenni fléttuskipulagsins er að starfa- og afurðaskipulagið er notað samtímis pannig að valdbraut fléttast saman og starfsfólk sem pað á við um hafa pannig tvo yfirmenn. Skipulagið hentar vel fyrir stærri fyrirtæki sem starfa í flóknu og oft alpjóðlegu umhverfi par sem samræmingargetan er aukin með fléttunni. Gallar eru hins vegar peir að togstreita getur myndast, skipulagið er flókið og stjórnunarkostnaður er hár (Daft, 1992; Runólfur Smári Steinpórsson o.fl., 1995; Jones 2001).

Verkefnamiðað skipulag einkennist af pví að verkefni eru útgangspunkturinn í skipu- 
laginu. Petta skipulag gerir kleift að takast á við aðstæður eins og aukið flækjustig, sífellt meiri tæknilega óvissu, hraðar breytingar á markaðsaðstæðum, aðlögun að óskum viðskiptavina og mikilvægi pess að geta unnið pvert á einingar og færni í fyrirtækjum (Hobday, 2000; Sydow, Lindkvist og DeFillippi, 2004). Verkefnamiðað skipulag er notað í margs konar skipulagsheildum og pað er oft notað í stað fléttuskipulags (Hobday, 2000). Helstu kostir verkefnamiðaðs skipulags eru sveigjanleikinn og getan til aðlögunar á mörgum sviðum, s.s. í tengslum við nýsköpun og pátttöku viðskiptavina í starfseminni, ekki síst pegar fyrirtæki eru í mörgum verkefnum. Helstu gallar eru að verkefnaskipulag hentar ekki pegar um fjöldaframleiðslu er аð ræða eða pegar starfsemi byggir á miklu umfangi innan viðvarandi ramma og aðstæðna (Hobday, 2000).

Að lokum í pessu yfirliti yfir helstu skipulagsgerðir er vikið að eignarhaldsskipulagi, p.e. skel fyrirtækja og eininga sem rekstrarlega starfa sjálfstætt undir miðlægri stjórn. Eignarhaldsskipulagið hefur ekki áhrif á daglegan rekstur en snýst að mestu um fjárhagslegt eftirlit með afkomu eininganna og miðlun upplýsinga um pá afkomu (Franko, 1974; Armour og Teece, 1978). Eignarhaldsskipulag er dreifstýrt í samanburði við aðrar skipulagsgerðir. Rekstur fyrirtækjanna innan skipulagsins er ekki á höndum peirra sem fara með samræmingu í skipulaginu og pað á bæði við um stefnu og starfsemi. Helsti galli skipulagsins er sú sundrung og ósamleitni sem pað getur haft í för með sér (Whittington og Meyer, 2000).

pegar rætt er um stöðu pekkingar á stjórnskipulagi fyrirtækja pá er komið fram bæði í inngangi og í kaflanum hér að framan að veruleg pörf er á nýjum rannsóknum og frekari próun kenninga á pessu sviði. Segja má að alpjóðlega Innform rannsóknin (Pettigrew o.fl., 2003), sem hefur verið fyrirmyndin að tveimur rannsóknum hér á landi, hafi verið tilraun til að koma fram með nýja pekkingu um skipulag fyrirtækja. Eins og greint er frá í grein Einars Svanssonar og Runólfs Smára Steinpórssonar (2012) var megintilefnið með Innform rannsókninni að kanna hvort nýtt grunnform í skipulagi fyrirtækja væri farið að ryðja sér til rúms sem hefði stöðu til jafns við U-formið, p.e. starfaskipulagið, eða M-formið, p.e. afurðaskipulagið, sem hefur haft yfirburðastöðu sem ríkjandi form á Vesturlöndum (Whittington og Meyer, 2000). Tilefnið á bak við Innform rannsóknina var spurningin um pað hvort svokallað $\mathrm{N}$-form, p.e. nýtt og lausbundnara skipulagsform sem byggði m.a. á tengslum og tengingu milli aðila, pekkingu og færni starfsfólks, láréttum samskiptum og tímatengdum lausnum, væri að öðlast sess til jafns við hin hefðbundnari form (Hedlund, 1994; Pettigrew og Massini, 2003).

Innform rannsóknin skilaði framlagi sem hefur verið fjallað um með hliðsjón af peim premur meginsviðum sem rannsóknin beindist að (Einar Svansson og Runólfur Smári Steinpórsson, 2012). Í fyrsta lagi var staðfest próun á skipulagi, pegar um stærri fyrirtæki er að ræða, í átt til aukinnar dreifstýringar og verkefnavæðingar í skipulagi samhliða fækkun stjórnprepa. Petta tengist áherslum sem fela í sér aukna valddreifingu, umboðsveitingu, liðsvinnu pvert á deildir og aukna nýtingu á tæknilausnum til að auðvelda samskipti og boðskipti (Pettigrew og Massini, 2003). Раð fékkst hins vegar ekki staðfest að nýtt grundvallarform á skipulagi fyrirtækja væri tekið að ryðja sér rúms til jafns við starfaskipulag og afurðaskipulag heldur eru nýjar áherslur og meiri fókus á lárétta pætti skipulagsins viðbót sem finnur sér farveg innan og með hefðbundnari lausnum (Pettigrew og Massini, 2003; Einar Svansson og Runólfur Smári Steinpórsson, 2012). Í öðru lagi miðaði Innform rannsóknin á að skoða próun ferla og áherslur í framvindu athafna varðandi samskipti og tengsl. Í brennidepli rannsóknarinnar voru boðmiðlun og samskipti, bæði lárétt og lóðrétt, próun aðferða við starfsmanna- og mannauðsmál, auk próunar í kerfum og tækni (Fenton og Pettigrew, 2000). Pessar áherslur í Innform rannsókninni kölluðust á við pá sýn að í pekkingar- og lærdómssamfélagi væri próunin í átt að meiri sveigjanleika og meiri virkni allra peirra sem koma að starfsemi fyrirtækja og stofnana (O'Reilly og Tushman, 2004; Pettigrew o.fl., 2003). Í priðja 
lagi var í alpjóðlegu Innform rannsókninni vikið að mörkum og umfangi í starfsemi fyrirtækja. Aðaláherslan var að kanna hvort pað væri samræmi í próun á skipulagi fyrirtækja, annars vegar varðandi skipulagseinkennin sjálf og ferlana og hins vegar varðandi próun á stærð og ytri mörkum fyrirtækjanna og viðskiptaeininganna. Venjulega er samhengi á milli fjölda prepa í stigveldi fyrirtækja og stærð peirra. Spurningin var pví hvort pað væri leitni í pá átt að fyrirtæki væru að afmarka sig meira við kjarnastarfsemi og hvort pað væri aukin áhersla á lausnir eins og útvistun og samstarf við önnur fyrirtæki (Fenton og Pettigrew, 2000).

Pær ritrýndu greinar sem hafa verið birtar á Íslandi um próun á stjórnskipulagi fyrirtækja á Íslandi hafa allar að geyma yfirlit yfir stöðu pekkingar á sviðinu. Hér að framan hefur verið fjallað um pessa stöðu, bæði út frá hefðbundnum kenningum og pað hefur líka verið vikið að viðfangsefni nýrri rannsókna eins og alpjóðlegu Innform rannsóknarinnar, par sem sú rannsókn er fyrirmynd að rannsóknum sem hafa verið gerðar hérlendis. Umfjöllunin um stöðu pekkingar er ekki tæmandi en áherslan er einkum að styðja við umræðu um niðurstöður peirra rannsókna sem koma fram í pessari grein, par með talið að fara einnig stuttlega yfir nýja strauma í skipulagsfræðunum.

\section{Nýir straumar innan skipulagsfræða}

Hin síðari ár hafa hraðar tæknibreytingar, vaxandi pólitískur óstöðugleiki og viðvarandi efnahagsleg óvissa undirstrikað mikilvægi pess að fyrirtæki og stjórnendur peirra tileinki sér hæfni til að laga sig að breyttu ástandi og oft á tíðum pversagnakenndum (e. paradoxical) aðstæðum (Pettigrew o.fl., 2003). Pau fyrirtæki sem hafa borið sigur úr býtum í alpjóðlegu markaðsumhverfi eru pau sem hafa sýnt viðbragð í tíma, verið sveigjanleg og verið fljót að koma með nýjungar á markað til að mæta nýjum pörfum. Til viðbótar hafa pessi fyrirtæki jafnan stjórnendur sem búa yfir getu til að sampætta og endurskipuleggja innri og ytri hæfni fyrirtækisins á árangursríkan hátt. Petta samkeppnisforskot framangreindra fyrirtækja nefndu Teece og Pisano (1994) kvika færni (e. dynamic capability) sem liggur til grundvallar nýjum straumum í skipulagi og stjórnun. Kvik færni verður skilgreind nánar í kafla 3.2. Að baki hinum nýju straumum eru jafnan eldri kenningar skipulagsfræðanna. Innan kenninga um aðstæðnasýn (e. contingency theory) er talið að fyrirtæki verði mun skilvirkari ef útfærsla skipulagsins passar við hlutverk peirra (Pugh, 1973). Til nánari útskýringar er hægt að líta til kenninga Burns og Stalker (1961) um vélrænt og lífrænt skipulagsform. Fyrirtæki ættu að taka upp vélrænt form ef hlutverk peirra er einfalt, stöðugt og miðar helst að pví að ná skilvirkni. Lífrænt form hentar betur fyrir hlutverk sem eru flókin og breytileg og parfnast sveigjanleika.

Í grein um niðurstöður fyrstu Innform rannsóknarinnar á Íslandi 2004-2007 (Einar Svansson og Runólfur Smári Steinpórsson, 2012), var rætt um framlag alpjóðlegu Innform rannsóknarinnar til pekkingar á nýbreytni í skipulagi fyrirtækja. Par var m.a. varpað ljósi á hugtakið tvenndir (e. dualities). Í samhengi við pær breytingar sem nefndar eru hér að ofan hafa fræðimenn viljað nota tvenndir sem orð yfir samhangandi pætti sem taka breytingum samtímis en á mismunandi hátt. Einnig hafa skipulags- og stjórnunarfræðin viljað skilgreina pversagnir (e. paradox) á svipuðum nótum en hugmyndafræðina má skilgreina sem gagnstæða en á sama tíma samhangandi pætti sem virðast vera skynsamlegir einir og sér en virðast órökréttir og fjarstæðir samtengdir (Lewis, 2000). Hugtakið hefur verið nýtt til að greina hegðun fyrirtækja í ástandi sem markast af breytingum, samkeppni og óróa. Pversagnir geta reynst stjórnendum gagnlegar í að meta árekstra í skipulagi fyrirtækja eða árekstra sem myndast pegar reynt er að takast á við tvær eða fleiri mótsagnakenndar andstæður.

\subsection{Fyrirtæki með jafnvíga færni}

Nýlegar rannsóknir á skipulagi fyrirtækja hafa tekið framangreindar áskoranir til skoðunar á sviði sem lýsa má sem áherslu á jafnvíga færni (e. ambidexterity) í skipulagi og starf- 
semi fyrirtækja (Birkinshaw og Gibson, 2004). Hæfileiki manna að vera jafnvígur á báðar hendur (e. ambidextrous) hefur verið notaður sem myndlíking til að skilgreina pessa færni fyrirtækja en viðfangsefnið hefur fengið vaxandi athygli innan skipulagsfræðanna. Nálgunin byggir á hugmyndum James March (1991) um að geta fyrirtækja til aðlögunar og breytinga snúist um færni peirra við að kanna (e. explore) nýja möguleika á sama tíma og pau nýti (e. exploit) sem best pá hæfni og auðlindir sem fyrir eru innan fyrirtækisins. Samkvæmt March (1991) pá snýst færnin á sviði nýtingar um skilvirkni, stjórnun, stöðugleika og gæði. Hinsvegar snýst færnin á sviði könnunar um uppgötvanir, nýsköpun og sjálfstýringu. Hverju fyrirtæki er mikilvægt að búa yfir færni og getu á báðum sviðum en spenna og fórnarkostnaður (e. trade-off) getur myndast milli pessara gagnstæðu en pó samvirkandi pátta par sem peir keppa báðir um auðlindir sem iðulega eru af skornum skammti. Prátt fyrir að slík innri átök séu vissulega nauðsynleg pá er einnig mikilvægt fyrir fyrirtæki að koma á jafnvægi til að ýta undir velgengni og afkomu. March (1991) bendir pó á að par sem erfiðlega getur gengið að ná og viðhalda viðeigandi jafnvægi milli pess að viðhalda núverandi ástandi og ryðja brautina fyrir ný tækifæri, geta fyrirtæki átt pað á hættu að vera einungis miðlungs góð í hvoru tveggja; p.e. verið í stöðu sem svipar til pess sem Porter (1985) kallaði á sínum tíma að vera "stuck in the middle“.

Útskýringar á pessu nauðsynlega jafnvægi í getu og færni fyrirtækja hafa annaðhvort verið settar í samband við „,skipulagslega pætti“ innan fyrirtækja (e. structural ambidexterity) eða pá pætti sem eru lýsandi fyrir ",annað samhengi“ innan fyrirtækja (e. contextual ambidexterity). Раð fyrrnefnda gerir ráð fyrir að leysa megi átök sem myndast, milli pess að nýta og kanna, í gegnum tilfærslur í skipulaginu (Tushman og O’Reilly, 2013) en pað síðara telur átökin leysast fyrir tilstilli einstaklinganna í fyrirtækinu (Gibson og Birkinshaw, 2004).

Ein forsenda pess að fyrirtæki nái jafnvægisástandi er hversu vel stjórnendur ná að stýra fyrirtækjunum í átt að pessu jafnvægi. Tushman og O’Reilly (1997) telja stjórnendateymið vera drifkraft pess að jafnvæginu sé náð par sem innri ferlar gera peim kleift að spila úr miklu magni upplýsinga og valkosta við ákvörðunartöku, ásamt pví að hafa pað hlutverk að takast á við pær pversagnir og tvíræðni sem við er að glíma. Peir benda á að áskoranirnar við að koma jafnvæginu á geti verið mismunandi eftir stöðu stjórnenda. Er pað forstjórans að grípa inn í eða framkvæmdastjórnarinnar? (Tushman og O’Reilly, 2013). Samskonar hugmyndir liggja að baki rannsóknum peirra Mihalache, Jansen, Van de Bosch og Volberda (2014) og Lubatkin, Simsek, Ling og Veiga (2006) par sem jafnvægið er skoðað út frá samtengdri hegðun (e. behavioral integration) stjórnenda. Að peirra mati er enginn hópur innan fyrirtækja í betri stöðu til að ná fram jafnvæginu en stjórnendur. Mat Mihalache o.fl. (2014) er að pað sé auðveldara að koma á jafnvægi en flestar rannsóknir benda til. Mögulega sé aðeins pörf á að forstjóri fyrirtækis sé peim leiðtogahæfileikum gæddur að framkalla samstilltari hegðun stjórnenda innan stjórnendateymisins, enda er hann í peirri einstöku stöðu að vera sá aðili sem hefur tækifæri til að velja, hvetja og pjálfa stjórnendur sína til að svo megi verða.

\subsection{Kvik færni fyrirtækja}

Frá lokum 20. aldarinnar hefur óvægin samkeppni á mörgum mörkuðum gert pað að verkum að fyrirtæki hafa sífellt purft að aðlaga sig að breyttum aðstæðum með pví að endurnýja og endurskapa auðlindir sínar og hæfni. Geta til pess hefur verið nefnd „kvik færni“ (e. dynamic capabilities) og er pað eitt af nýrri hugtökum sem hafa verið notuð til pess að útskýra af hverju sum fyrirtæki lifa breytingar og samkeppni af en önnur ekki. Að grunninum til byggir hugtakið á auðlindakenningunni (e. resource-based view) (Wernerfelt, 1984; Barney, 2001) en sú kenning hefur pó ekki verið talin gefa nægjanlegar útskýringar á hvers vegna sum fyrirtæki, en önnur ekki, hafa náð samkeppnisforskoti í umhverfi sem einkennist af hröðum og ófyrirséðum breytingum (Eisenhardt og Martin, 2000).

Kenningin um kvika færni er enn á bernskuskeiði. Zahra, Sapienza og Davidsson (2006) 
hafa bent á að hugmyndafræðin feli í sér innbyrðis ósamræmi. Einnig hefur nálgunin við rannsóknirnar (e. empirical work) verið gagnrýnd en flestar byggja pær á eigindlegum gögnum tilviksrannsókna (Cepeda og Vera, 2007) og ekki hefur verið búið til mælitæki sem býður upp á megindlegar niðurstöður varðandi kvika færni. Teece $(1997,2007)$ hefur viljað tengja kvika færni við samkeppnisforskot fyrirtækja en samkvæmt Zott (2003) pá er pað enn óljóst að hvaða leiti kvik færni hefur áhrif á samkeppnisforskotið. Sambærileg við tengingu kvikrar færni við árangur en sú umræða er að mati Williamson (1999) byggð á tvítekningu (e. tautological).

Upphaf kenningar um kvika færni má rekja til Teece, Pisano og Shuen (1997) sem drógu hugtakið fram sem nálgun við að skilja stefnumiðaðar breytingar. Kvik færni er skilgreind sem „hæfileiki fyrirtækja til að sampætta, byggja og umbreyta innri og ytri getu til að koma til móts við síbreytilegt umhverfi“ (Teece, o.fl. 1997, bls. 516). Nálgunin á að undirstrika lykilhlutverk stjórnenda við að aðlaga, breyta, skipuleggja og sampætta pá hæfni og auðlindir sem fyrirtækið býr yfir svo pær samsvari breytingum í umhverfi fyrirtækisins (O’Reilly og Tushman, 2008). Mikilvægt er að gera greinamun á „venjulegri“ hæfni fyrirtækja og kvikri. Sú fyrrnefnda snýst um getu og auðlindir fyrirtækja við að leysa úr vandamálum eða ná fram ákveðinni niðurstöðu. Kvik færni snýst hins vegar um að breyta eða endurstilla pá hæfni sem telst „,venjuleg“ innan fyrirtækisins (Winter, 2002). Samspil venjulegrar hæfni og kvikrar færni er pannig háð aðstæðum og hin kvika færni er lykillinn að pví að uppfæra venjulega hæfni fyrirtækja til að ná sem bestum árangri í starfsemi peirra.

Í pessum kafla um nýjar áherslur og strauma í skipulags- og stjórnunarfræðunum hefur umræðan verið afmörkuð við pað sem hefur komið fram um mikilvægi pess að skipulagsheildir búi yfir „jafnvígri færni“ (e. ambidexterity) og kvikri færni (e. dynamic capabilities). Pessar áherslur tengjast niðurstöðum alpjóðlegu Innform rannsóknarinnar sem undirstrikaði mikilvægi pess að skipulagsheildir og stjórnendur peirra væru vakandi fyrir pversögnum í innri páttum og umhverfi skipulagsheilda og að nálgast pann vanda með stjórnun og skipulagi á grundvelli tvennda (e. dualities), sbr. umræðuna í upphafi pessa kafla. Áður en umræðan um pessar áherslur verður tekin lengra er mikilvægt að gera grein fyrir rannsóknunum sem eru kynntar í greininni, sérstaklega framhaldsrannsókninni innan verkefnisins Innform á Íslandi, sem gerð var árið 2015.

\section{Aðdragandi og aðferðafræði rannsóknanna}

Eins og kynnt var í inngangi pá er greint frá tveimur rannsóknum í pessari grein. Annars vegar er um samanburðarrannsókn að ræða á peim íslensku rannsóknum sem gerðar hafa verið á stjórnskipulagi fyrirtækja. Hins vegar er fjallað sérstaklega um rannsókn sem nýlega var gerð og tengist rannsóknarverkefninu Innform á Íslandi sem vikið var að í inngangi greinarinnar.

Rannsóknin er framhaldsrannsókn á stjórnskipulagi íslenskra fyrirtækja sem gerð var fyrir árin 2004-2007 (Einar Svansson og Runólfur Smári Steinpórsson, 2012). Framhaldsrannsóknin hefur að geyma gögn frá árunum 2010 til 2014. Út frá gögnunum er hægt að rýna í niðurstöður um stjórnskipulag íslenskra fyrirtækja milli priggja tímabila, p.e. 20042007, 2007-2010 og 2010-2014, auk pess að skoða munstrið í heild. I pessu felst að gögnin eru frá pví fyrir hrun, yfir hrun árin og eftir hrun íslenska fjármálakerfisins. Pað var ekki fyrirséð við upphaf Innform rannsóknarinnar á Íslandi að hún myndi skila gögnum sem myndu gera pað kleift að rýna í próun og útfærslu á stjórnskipulagi íslenskra fyrirtækja á slíkum umbrotatímum. Nánar verður farið yfir niðurstöðurnar í umræðukafla greinarinnar.

\subsection{Samanburður á íslenskum rannsóknum}

Ákveðið var að draga fram pær íslensku rannsóknir sem skoðað hafa stjórnskipulag með tölfræðilegum gögnum. Í töflu 2 í kafla 5 er pessum samanburði gerð skil með yfirliti. 
Rannsóknirnar fimm eru merktar í tímaröð fyrirlagna en birting ritrýndra greina er efst í töflunni ásamt upphafsstöfum höfunda og ártali birtingar. Fjöldi fyrirtækja í úrtaki er borinn saman ásamt fjölda svara og svarhlutfalli. Til að freista pess að varpa sem skýrustu ljósi á stærð fyrirtækjanna í hverri rannsókn er birt hlutfall fjölda starfsmanna undir 20, 50 eða 100 starfsmönnum. Síðan er hlutfall tegunda stjórnskipulags tilgreint. Petta hlutfall er rúnnað af í næsta heila tölustaf. Í nokkrum tilvikum er byggt á aflestri súlurita par sem ekki eru birtar tölur í töflum í fyrri greinum. Undir töflu 2 eru tilgreind frávik og frekari skýringar á samanburðinum eftir pví sem við á.

\subsection{Framkvæmd Innform framhaldsrannsóknarinnar}

Innform-spurningakönnunin var lögð fyrir öðru sinni árið 2015 en könnunin tók til tímabilsins 2010-2014. Раð markmið var sett við framkvæmd fyrri könnunarinnar (árið 2007) að hún yrði endurtekin hér á landi til að sjá hvernig skipulag og umfang (e. scope) íslenskra fyrirtækja væri að próast. Einnig átti langtímarannsókn sem framkvæmd væri með sama mælitæki að geta gefið betri vísbendingar um hvaða stjórnunaráherslur og stefna væri að ýta undir sem bestan árangur við íslenskar aðstæður til lengri tíma litið. Рað var jafnframt von rannsakenda í fyrri rannsókninni að ítarlegri gögn sem næðu yfir lengri tíma gætu nýst bæði innlendum og erlendum fræðimönnum og stjórnendum. Jafnframt var talið að stytta pyrfti spurningalistann til að einfalda fyrirlögnina (Einar Svansson og Runólfur Smári Steinpórsson, 2012). Hér á eftir verður farið yfir aðferðafræði Innform könnunarinnar eins og hún kemur fyrir í báđum fyrirlögnunum sem framkvæmdar hafa verið á Íslandi. Til að koma í veg fyrir misskilning pá verður hér talað um könnunina sem náði yfir tímabilið 2004-2007 sem INNFORM 2007 og pá seinni sem náði yfir árin 2010-2014 sem INNFORM 2014.

Par sem INNFORM-spurningakönnunin var unnin að erlendri fyrirmynd purfti í upphafi að pýða spurningalistann yfir á íslensku ásamt pví að fá mat á lengd hans áđur en hann yrði lagður fyrir í endanlegri mynd. Könnunin var lögð fyrir nema í tveimur námskeiðum í Viðskipta- og hagfræðideild Háskóla Íslands. Urtakið innihélt 126 nema og bárust 40 svör sem samsvaraði 31,7\% svarhlutfalli. Eftir framkvæmd INNFORM 2007 var forsvarsmönnum ljóst að spurningalistinn væri of erfiður yfirferðar par sem stjórnendur pyrftu að bera saman tvö tímabil. Var pví ákveðið að stytta spurningalistann fyrir fyrirlögnina sem gerð var árið 2015, úr 37 spurningum (188 breytur) yfir í 28 spurningar (125 breytur).

İ báðum Innform spurningakönnununum var listi fenginn hjá Hagstofu Íslands yfir fyrirtæki sem höfðu 50 eða fleiri starfsmenn á launaskrá. Í INNFORM 2007 innihélt listinn pýði 200 fyrirtækja en í INNFORM 2014 innhélt hann 332. Samkvæmt skilgreiningu alpjóðlegu Innform-rannsóknarinnar um tegund atvinnurekenda, pá mega aðeins taka pátt fyrirtæki sem hafa innlent eignarhald (e.domestically owned enterprises) og pví urðu eftir í úrtakinu 192 fyrirtæki í INNFORM 2007 og 297 fyrirtæki í INNFORM 2014. Pýði fyrirlagnanna myndaði pví úrtak kannananna fyrir hvort ár.

Tafla 1. Samsetning pýðis og svarhlutfalls 2004-2007

\begin{tabular}{lcccc}
\hline & \multicolumn{2}{c}{ Pýðið } & \multicolumn{2}{c}{ Svarhlutfall í úrtaki } \\
Fjöldi starfsmanna á launaskrá í hverju fyrirtæki & $\mathbf{2 0 0 4 - 2 0 0 7}$ & $\mathbf{2 0 1 0 - 2 0 1 4}$ & $\mathbf{2 0 0 4 - 2 0 0 7}$ & $\mathbf{2 0 1 0 - 2 0 1 4}$ \\
\hline 100 eða færri starfsmenn & $35 \%$ & $50 \%$ & $26 \%$ & $44 \%$ \\
100 - 200 starfsmenn & $36 \%$ & $24 \%$ & $33 \%$ & $23 \%$ \\
200 eða fleiri starfsmenn & $36 \%$ & $26 \%$ & $33 \%$ & $34 \%$ \\
\hline
\end{tabular}

Svartímabil INNFORM 2007 könnunarinnar var frá 16. maí til 25. júní árið 2005 en í INNFORM 2014 var svartímabilið tiltölulega langt eða alls 8 vikur með hléi vegna sumarfría: 
15. apríl-3. júní og 7.- 14. september 2015. Eintak af könnuninni var sent í pósti á skráð heimilisfang allra fyrirtækjanna og stílað á æðsta stjórnanda pess. Einnig var hverjum pessara stjórnanda sendur tölvupóstur par sem könnunin var kynnt og peir beðnir um að taka pátt eða koma henni í hendur á öðrum stjórnanda innan fyrirtækisins sem hefði yfirsýn yfir pað tímabil sem könnunin náði til. Í fyrirlögninni 2014 var ákveðið að bjóða stjórnendum einnig upp á að svara spurningakönnuninni í gegnum netkönnun til að auka á svarhlutfallið en netkönnunin var sett upp í gegnum LimeSurvey forritið. Spurningalistinn var útfærður pannig að fyrst voru bakgrunnsspurningar en pær síðari fullyrðingar sem stjórnendur voru beðnir um að taka afstöðu til. Flest svörin voru gefin upp á fimm arma jafnbilakvarða (e. Likert) en einnig voru svör sett fram á raðkvarða og var pá oftast verið að bera saman tímabilin. Af pessum sökum var yfirferð spurningalistans frekar flókin.

Í báðum fyrirlögnunum var ítrekun send í tölvupósti á stjórnendur ásamt pví að reynt var að hringja til peirra. Af 192 útsendum listum í INNFORM 2007 bárust 62 svör og svarhlutfallið var pví 32,3\%, Af 297 útsendum listum í INNFORM 2014 bárust 100 svör og var svarhlutfallið pví 29,7\%. Svarhlutföllin úr báðum fyrirlögnum póttu viðunandi ef tekið er mið af erlendu Innform-könnununum sem lagðar höfðu verið fyrir á árunum 1992-1997. Svarhlutfall beggja íslensku rannsóknanna er með pví hæsta sem fengist hefur úr Innform á heimsvísu en til samanburðar má nefna að í Bandaríkjunum var svarhlutfallið aðeins $7 \%$ (Pettigrew o.fl., 2003).

Hvað áreiðanleika Innform kannananna varðar pá var sama spurningalista fylgt en pó með peirri breytingu að hann var styttur úr 37 í 28 spurningar í INNFORM 2014. Sama snið var á fyrirlögnunum en pó var spurningalistinn einnig sendur út sem netkönnun í INNFORM 2014 til að auka á svarhlutfall. Pað mætti pví segja að könnunin sé áreiðanleg hvað form og aðferðir varðar. Tölfræðivinnsla beggja kannanna var með sama sniði. Vinnslan fór fram í gegnum SPSS tölfræðiforritið og gröf og töflur settar upp í Excel. Við yfirferð á spurningalistunum var tekið tillit til frávika. Segja má að bæði innra og ytra réttmæti sé tryggt út frá framangreindu en eins og ofar greinir pá myndaði pýðið jafnframt úrtak hvorrar fyrirlagnar fyrir sig.

Hér hefur verið vikið að aðferðafræði Innform rannsóknarinnar til að varpa ljósi á samhengið sem er á milli alpjóðlegu rannsóknarinnar og rannsóknanna á stjórnskipulagi íslenskra fyrirtækja á árunum 2004-2007 og 2010-2014. Áður en gerð verður frekari grein fyrir Innform rannsókninni á Íslandi 2010-2014 verður farið yfir samanburð á peim ritrýndu rannsóknum sem hafa verið gerðar á stjórnskipulagi íslenskra fyrirtækja.

\section{Rannsóknir á skipulagi íslenskra fyrirtækja}

Stjórnskipulag íslenskra fyrirtækja eins og mörg önnur fyrirbæri af viðskiptafræðitoga hér á landi er hvergi nærri fullrannsakað. Engu að síður hafa verið birtar fjórar rannsóknir á ritrýndum vettvangi og nýleg rannsókn er jafnframt fyrirliggjandi, en sú rannsókn verður kynnt nánar í næsta kafla.

Pegar rýnt er í pessar rannsóknir kemur í ljós að pær byggja á gögnum um skipulag fyrirtækja á Íslandi frá árunum 2004 til 2016. Ef horft er til pess hvenær rannsóknirnar eru birtar pá koma fyrstu niðurstöður fram árið 2006, síðan árið 2008, pá 2012, svo 2015 og loks árið 2016. Í fyrstu greininni sem birtist árið 2006, Stjórnunaraðferðir og skipulag íslenskra fyrirtækja (Ingi Rúnar Eðvarðsson, 2006), var ákveðinn tónn sleginn. Par var sjónum beint að skipuritum, stjórnunaraðferðum og útboði verkefna, eða samstarfi, við önnur fyrirtæki. Greinin byggði á gögnum úr rannsókn sem hafði verið gerð árið 2004. Niðurstöður rannsóknarinnar sýndu að staðsetning eða starfsgrein hafði lítil áhrif á skipulag fyrirtækja. Hinsvegar hafði stærð fyrirtækja og menntun stjórnenda mikil áhrif. Úrtakið í rannsókninni var 905 fyrirtæki með fleiri en fimm starfsmenn, en svör bárust frá 265 fyrirtækjum. Um 61\% fyrirtækjanna hafði 20 starfsmenn eða færri. Algengasta stjórnskipulagið reyndist vera starfaskipulag (67\%) en fléttuskipulag kom par næst með um 18\%. Stærð 
fyrirtækjanna reyndist hafa tölfræðileg tengsl við skipulag á pann veg að fyrirtæki með færri en 50 starfsmenn voru talin marktækt líklegri til að nota starfaskipulag. Meðalfjöldi prepa frá æðsta til lægsta stjórnanda var tvö (prjú ef prepin almennir starfsmenn, millistjórnendur og framkvæmdastjóri voru lögð til grundvallar). Hvorki stjórnunaraðferðir eða skipulag virtist hafa tengsl við rekstrarárangur fyrirtækjanna sem telst athyglisvert (Ingi Rúnar Eðvarðsson, 2006).

Tveimur árum síðar var birt grein um Skipulagsform íslenskra fyrirtækja (Ingi Rúnar Eðvarðsson og Guðmundur Kristján Óskarsson, 2008). Par var byggt á rannsókn sem gerð var árið 2007. Sú grein beindist að pví eins og nafnið ber með sér að kanna enn frekar hvaða skipulagsform eru ríkjandi í íslenskum fyrirtækjum. Einnig var markmiðið að skoða áhrif stærðar og rekstrarumhverfis á skipulag. Úrtakið var að pessu sinni tæp 500 fyrirtæki með fimm starfsmenn eða fleiri og bárust 222 svör. Um 60\% fyrirtækjanna voru með 20 starfsmenn eða færri. Niðurstaðan sýndi að stærð fyrirtækjanna hafði talsverð áhrif á marga pætti skipulags. Stærri fyrirtækin voru með flóknara og formlegra skipulag en pau smærri. Stærð fyrirtækjanna reyndist ekki hafa tengsl við árangur eða skipulag peirra. Starfaskipulag virtist tíðara hjá fyrirtækjum í stöðugu rekstrarumhverfi. Algengasta tegund skipurita var starfaskipulagið með 66\% og næst kom fléttuskipulag með um 16\%. Litlar breytingar koma pví fram í gögnunum frá árinu 2007 samanborið við fyrstu rannsóknina sem gerð var 2004. Stærri fyrirtækin notuðu frekar fléttuskipulag og pau smærri starfaskipulag (Ingi Rúnar Eðvarðsson og Guðmundur Kristján Óskarsson, 2008).

Nýlega birtist svo priðja greinin frá Inga Rúnari Eðvarðssyni og samstarfsaðilum hans, p.e. Skipulagsform íslenskra fyrirtækja í sveiflukenndu viðskiptaumhverfi 2007-2016 par sem nýjar niðurstöður voru kynntar (Ásta Dís Óladóttir, Guðmundur Kristján Óskarsson og Ingi Rúnar Eðvarðsson, 2016). Pessar niðurstöður byggðu á sama grunni og grein Inga Rúnars og Guðmundar Kristjáns frá 2008. Gögnin frá fyrirlögninni 2007 eru borin saman við nýja fyrirlögn frá 2016. Markmið rannsóknarinnar var svipað og 2007 en nokkrum nýjum spurningum bætt við, m. a. spurningu um pað hvort hagsveiflur hafi áhrif á skipurit og hvort stjórnendur breyti skipulagi pegar prengir að í rekstrinum. Úrtakið 2016 var svipað og 2007 eða um 500 fyrirtæki og svöruðu um helmingi færri árið 2016 eða 120 stjórnendur. Stærð fyrirtækjanna virðist meiri í rannsókninni frá 2016 en 65\% fyrirtækjanna voru með 50 starfsmenn eða færri en pað hlutfall var tæp 80\% í könnuninni frá 2007. Niðurstöður benda til pess að hagsveiflur hafi ekki áhrif á stjórnskipulag. Stærð fyrirtækjanna hafði hinsvegar áhrif á nokkra pætti skipulags peirra og var pað í samræmi við niðurstöðurnar frá 2007. Stærri fyrirtækin (með fleiri en 50 starfsmenn) voru oftar með sampykkt stjórnskipulag en pau minni. Starfaskipulagið er algengasta skipurit í pessari könnun eða um 45\% á móti 66\% árið 2007 (Ásta Dís Óladóttir, Guðmundur Kristján Óskarsson og Ingi Rúnar Eðvarðsson, 2016).

Eins og greint var frá í inngangi pá var rannsóknarverkefnið Innform á Íslandi sett af stað á svipuðum tíma og rannsóknir Inga Rúnars Eðvarðssonar á skipulagi hófust. Rannsóknarverkefnið var að erlendri fyrirmynd, sbr. umfjöllun um alpjóðlegu rannsóknina í kaflanum um stöðu pekkingar á skipulagi fyrirtækja. Vinnan við íslenska Innform rannsóknarverkefnið hófst árið 2005 (Runólfur Smári Steinpórsson, 2008). Fyrsta rannsóknin var síðan gerð árið 2007 og pá var safnað gögnum um stjórnskipulag íslenskra fyrirtækja á árunum 2004 og 2007. Vegna umfangs rannsóknarinnar voru niðurstöður fyrst birtar úr ákveðnum hlutum íslensku rannsóknarinnar (Einar Svansson, 2008b). Var par fjallað um jákvæð tengsl á milli formlegrar stefnu og árangurs íslenskra fyrirtækja. Niðurstöður sýndu árangur af endurskipulagningu vinnuferla sem virðist vera víðtækur hjá fyrirtækjunum en um 90\% fyrirtækjanna höfðu endurskipulagt vinnuferla á árunum 2004-2007. Fleiri rannsóknir tóku fyrir afmarkaða pætti í Innform rannsókninni (Bergdís Björk Sigurjónsdóttir, 2009; Pórhildur Guðsteinsdóttir, 2009).

Í framhaldi var svo birt ítarleg grein á grundvelli Innform gagnanna undir heitinu Skipulag íslenskra fyrirtækja 2004-2007 (Einar Svansson og Runólfur Smári Steinpórsson, 
2012). Viðfangsefni greinarinnar var að fjalla um próun á skipulagi, ferlum og umfangi í starfsemi 192 stærstu íslensku fyrirtækjanna sem var pýðið en svör bárust frá 62 fyrirtækjum. Markmiðið var að kanna hvort ný skipulagsform væru tekin að ryðja sér til rúms eða hvort ný form væru að próast samhliða eldri formum. Helstu niðurstöður voru pær að stærstu fyrirtækin lögðu einna mest áherslu á afurðatengt stjórnskipulag par sem fókus var á vörur og pjónustu (tæp 90\% árið 2007) en pau lögðu jafnframt aukna áherslu á viðskiptavininn (75\%) í skipulagi sínu. Meðalfjöldi prepa frá æðsta til lægsta stjórnanda með rekstrarábyrgð fór úr 2,9 upp í 3,0 á tímabilinu. Stór hluti fyrirtækjanna (um 70\%) studdist hins vegar líka við starfaskipulag. Pessar niðurstöður benda til pess að skipulag stórra íslenskra fyrirtækja sé um margt sambærilegt við pað sem fram kom í peim erlendu rannsóknum sem miðað var við. Íslensku niðurstöðurnar bentu líka til pess að skipulag íslensku fyrirtækjanna hafi verið að próast á pessu tímabili. Verkefnaskipulag var að ryðja sér til rúms, hækkaði úr 32\% upp í 52\% og notkun fléttuskipulags jókst úr 18\% upp í 31\% á tímanum sem rannsóknin náði til. Breytingar á umfangi, útvistun og samstarfi milli fyrirtækja mældust frekar litlar yfir tímabilið og breytingarnar hér á landi gengu ekki eins langt og virtist hafa verið tilfellið í Evrópu áratugi fyrr. Рað var líka athyglisvert að próunin í átt til meiri notkunar á verkefnaskipulagi var mun skarpari í Evrópu. Próun ferla á Íslandi sýndi að aukin áhersla á mannauðsstjórnun skar sig úr með mestu breytinguna petta tímabil.

Innform rannsóknin á stjórnskipulagi íslenskra fyrirtækja var síðan endurtekin á árinu 2015 (Anna Marín Pórarinsdóttir, 2017). Gagnaöflunin fór fram árið 2015 og náði til áranna 2010 og 2014. Byggt var á sama Innform spurningagrunni og hafði verið gert árið 2007. Í næsta kafla er gerð ítarleg grein fyrir niðurstöðum úr könnunum Innform rannsóknarinnar fyrir árin 2004-2014 en áđur en að pví kemur er út frá töflu rýnt nánar í pær fimm rannsóknir sem hér hefur verið fjallað um og gerður nánari samanburður á peim. Í aðferðafræðikaflanum hér að framan, sjá kafla 3.1, var gerð grein fyrir nálguninni við samanburðinn og gerð töflu 2.

Tafla 2. Yfirlit íslenskra rannsókna um skipulag fyrirtækja 2004-2016

\begin{tabular}{|c|c|c|c|c|c|c|c|}
\hline $\begin{array}{l}\text { Höfundur/Birting } \\
\text { Rannsókn }\end{array}$ & $\begin{array}{c}\text { IRE } 2006 \\
1 \\
05 / 062004\end{array}$ & \multicolumn{2}{|c|}{ ES,RSS 2012} & $\begin{array}{c}\text { IRE,GKÓ } 2008 \\
3 \\
11 / 122007\end{array}$ & \multicolumn{2}{|c|}{ AMP ofl. 2018} & $\begin{array}{c}\text { ÁDÓ ofl. } 2016 \\
5 \\
06 / 082016\end{array}$ \\
\hline Úrtak & 905 & 192 stærstu & 192 stærstu & 537 & 297 stærstu & 297 stærstu & $492^{* * * * * *}$ \\
\hline Fjöldi svara (n) & $265^{* *}$ & 62 & 62 & $222^{* * * *}$ & 100 & 100 & 120 \\
\hline Fjöldi starfsmanna & $61 \%<20$ & $0 \%<50$ & $0 \%<50$ & $92 \%<100$ & $0 \%<50$ & $0 \%<50$ & $65 \%<50$ \\
\hline Starfaskipulag \% & 67 & 73 & 74 & 66 & 57 & 66 & 46 \\
\hline Afurðaskipulag \% & 7 & $53-80^{* * *}$ & $74-90^{* * * *}$ & 5 & $49-77^{* * *}$ & $55-86^{* * *}$ & 14 \\
\hline Samstæðuskipulag & ekki mælt & 12 & 18 & ekki mælt & 15 & 23 & ekki mælt \\
\hline Eignarhaldsfélag & ekki mælt & 12 & 28 & ekki mælt & 19 & 23 & ekki mælt \\
\hline Annað & 1 & 0 & 0 & 8 & 0 & 0 & 23 \\
\hline
\end{tabular}

* $\quad$ Spurt aftur í tímann um árið 2004 í fyrirlögninni 2007 og um árið 2010 í fyrirlögn 2015

** n=175 í spurningu um stjórnskipulag og helsta skekkja að hlutfallslega fleiri fyrirtæki svara á landsbyggðinni, 50\% úrtaks af höfuðborgarsvæði

*** Lægri talan er Viðskiptavinaskipulag og hærri talan er Vöru og pjónustuskipulag en hvorutveggja flokkast undir Afurðaskipulag

**** n=199 í spurningu um stjórnskipulag og Um helmingur fyrirtækja af höfuðborgarsvæði og 25\% af Eyja- 
fjarðarsvæði sem skekkir úrtakið m.v. landið allt

***** Fyrirtækin valin af handahófi af Credit Info, stærri fyrirtæki en að jafnaði á Íslandi

Taflan sýnir fimm rannsóknir með sjö mælingum sem eru framkvæmdar af tveimur teymum tengdra rannsakenda annaðhvort einum eða fleirum peirra í hvert sinn. Rannsóknir 1, 3 og 5 eru gerðar af rannsóknarhópi A: Inga Rúnari Eðvarðssyni og félögum (Guðmundur Kristján Óskarsson (3,5) og Ásta Dís Óladóttir (5)) en rannsóknir 2 og 4 af rannsóknarhópi B: Runólfi Smára Steinpórssyni og samstarfsaðilum (Einar Svansson (2) og Anna Marín Pórarinsdóttir (4)). Aðalmunurinn á nálguninni í rannsóknum pessara tveggja hópa er stærðin á peim fyrirtækjum sem valin eru í úrtak rannsóknanna. Ingi Rúnar og félagar eru með lagskipt úrtak allra stærða fyrirtækja í rannsóknum 1 og 3 sem byggir á ca 50\% fyrirtækja af höfuðborgarsvæðinu, 25\% af Eyjafjarðarsvæði og 25\% af landsbyggðinni en úrtakið í síðustu rannsókn peirra (rannsókn 5) er tilviljanakennt og valið af Credit Info. Af peirri ástæðu eru fyrirtækin stærri í rannsókn 5 en rannsóknum 1 og 3 frá rannsóknarhópi A en samt minni en fyrirtækin í úrtaki rannsóknarhóps B par sem úrtakið í rannsóknum 2 og 4 var valið á sama hátt í báðum rannsóknum og hafði að geyma öll íslensk fyrirtæki með fleiri en 50 starfsmenn (e. domestically owned enterprizes $>50$ employees). Svarhlutfallið er sambærilegt í nánast öllum pessum rannsóknum eða um pað bil 30\%, en rannsókn 3 sker sig aðeins úr með $46 \%$ svarhlutfall.

Aðalmunurinn á pessum rannsóknum er pví sá að fyrirtækin hjá rannsóknarhópi A eru með mun færri starfsmenn (meirihluti fyrirtækja sem svara eru með færri en 50 starfsmenn) og vegna lagskiptingar úrtaks í rannsóknum 1 og 3 er aðeins unnið með tilviljunarkennt úrtak af öllu landinu í rannsókn 5. Fjöldi svara (n) er á hinn bóginn meiri hjá rannsóknarhópi A pótt svarhlutfall sé svipað. Hvað rannsóknir 2 og 4 varðar má sjá að hjá rannsóknarhópi B eru úrtak og pýði í raun pað sama pví allt býði fyrirtækja stærri en 50 manns er spurt, sem ætti að styrkja niðurstöður B pótt færri svari. Hinsvegar er rétt að vekja athygli á pví að fyrri mælingin í rannsókn 2 og 4 byggir á pví að spyrja 3 ár aftur í tímann um pað hvernig skipurit var pá í sama fyrirtæki. En jafnframt er notaður paraður samanburður sem sýnir marktækar niðurstöður í hvorri rannsókn $(2,4)$.

Athyglisvert er að skoða yfirlit um próun stjórnskipulags (tegunda skipurita) í öllum pessum rannsóknum. Starfaskipulag virðist vera sambærilegt hlutfall í peim öllum eða á bilinu 46-74\% og virðist stærð fyrirtækja í úrtakinu ekki hafa nein teljandi áhrif á pá niðurstöðu sem er athyglisvert. Innform rannsóknirnar $(2,4)$ gefa til kynna að starfaskipulag sé áberandi bæði í litlum og stórum fyrirtækjum á Íslandi, enda eru pær að mæla breytingar á miklu breytingaskeiði. Fyrirtækin stækkuðu hratt fyrir hrun og pá verður skipulagið blandað til að byrja með pótt önnur skipulagsform taki við að hluta og bætist við. Er petta í samræmi við erlendu Innform rannsóknirnar sem sýna að úrtak í hinum löndunum var með mun stærri fyrirtæki en eru hér að meðaltali. Einnig eru stór íslensk fyrirtæki smá á erlendan mælikvarða. Afurðaskipulag fylgir hins vegar öðru mynstri og er nánast ekki til staðar í rannsóknum 1,3,5 eða á bilinu 5-14\% en í rannsóknum 2,4 er pað á bilinu 49-90\% sem er í góðu samræmi við fyrri (alpjóðlegar) Innform rannsóknir ef miðað er við stærð fyrirtækjanna á bak við gögnin hjá rannsóknarhópi B. Svæðisskipulag fylgir jafnframt svipuðu mynstri, er mun sjaldgæfara hjá rannsóknarhópi A (4-7\%) en er á bilinu 25-41\% hjá hópi B. Fléttuskipulag er hinsvegar ekki jafn auðskýranlegt. Рað er erfitt að útskýra 18\% í rannsókn 1 ef miðað er við stærð fyrirtækjanna í peirri rannsókn, pví niðurstaðan er sambærileg við útkomu úr seinni rannsóknum með mun stærri fyrirtækjum. Verkefnaskipulag er ekki mælt sérstaklega hjá rannsóknarhópi A og gæti pað útskýrt lítinn mun í niðurstöðum um fléttuskipulag, pví ef hlutfall fléttuskipulags og verkefnaskipulags væri lagt saman kæmi í ljós mun skarpari mynd sem svo myndi endurspegla mun á stærð fyrirtækja í úrtaki rannsóknanna allra. Verkefnaskipulag er á bilinu 32-52\% hjá fyrirtækjum yfir 50 manns. Samstæðuskipulag og eignarhaldsfélög eru mæld í rannsóknum 2 og 4 og eru á bilinu 12-28\%. Í heildina litið má segja að pessar rannsóknir séu í pokkalegu samræmi við almenn fræði um skipulag og eins og vikið hefur verið að pá er hægt að útskýra 
mun á milli rannsóknanna að miklu leyti út frá stærð fyrirtækjanna.

Hér að framan hefur verið rýnt í pær heimildir sem hafa haft áhrif á umræðu um skipulag fyrirtækja á Íslandi og greina frá rannsóknum á stjórnskipulagi íslenskra fyrirtækja á ritrýndum vettvangi. Í umræðukafla greinarinnar verður unnið meira með petta efni með hliðsjón af markmiðum og rannsóknarspurningum greinarinnar. Nú verður vikið að fimmta kafla par sem niðurstöðum Innform rannsóknarinnar á Íslandi 2004-2014 verður gerð skil.

\section{Innform rannsóknin á Íslandi 2004-2014}

Í pessum kafla verður farið yfir niðurstöður Innform rannsóknarinnar á Íslandi fyrir og eftir hrun. Annars vegar verður farið yfir rannsóknina 2010-2014 (Anna Marín Pórarinsdóttir, 2017), p.e. rannsókn 4 í töflu 2 hér að framan, og hins vegar verður gerður ítarlegri samanburður við rannsóknina 2004-2007 (p.e. rannsókn 2 í töflu 2). Fyrst er farið yfir skipulagsbreytingar og pá breytingar á ferlum eins og umboðsveitingu starfsmanna.

\subsection{Niðurstöður könnunarinnar}

Eins og greint var frá í aðferðafræðikaflanum, sjá 4.2 hér að framan, pá var Innform spurningalistinn úr rannsókninni 2007 lagður á ný fyrir stjórnendur íslenskra fyrirtækja árið 2015 og voru stjórnendur beðnir um að svara spurningum miðað við stöðuna í peirra fyrirtækjum á annars vegar árinu 2010 og hins vegar árið 2014. Að mestu leiti var svarkerfi spurningalistans samkvæmt fimm arma jafnbilakvarða (e. Likert) en einnig voru nokkrar spurningar á raðkvarða. Fylgni (e. correlation) var reiknuð með Pearson $r$. Myndræn framsetning var framkvæmd í Excel.

\subsubsection{Próun á stærð íslenskra fyrirtækja}

Til að skoða próun á stærð fyrirtækja á Íslandi voru stjórnendur beðnir um að svara pví hversu margir starfsmenn (um pað bil) voru á launaskrá hjá fyrirtækinu árin 2014 og 2010? Niðurstöðurnar eru svo bornar saman við svörin frá árunum 2004 og 2007.

Á árunum 2004-2014 fóru fyrirtækin minnkandi hvað starfsmannafjölda varðar og er par mest minnkunin á miðju prepinu, fyrirtæki sem hafa 101-200 starfsmenn. Ef aðeins er litið á árin 2010-2014 má sjá að fyrirtækin stækkuðu dálítið á pví tímabili. Árið 2010 fjölgaði fyrirtækjum sem höfðu 100 eða færri starfsmenn um 17\%. Ekki var mikil hreyfing á peim fyrirtækjum sem voru með 201 eða fleiri starfsmenn á pessu 11 ára tímabili en pó má glögglega sjá að fyrirtækin fóru stækkandi fyrir hrun. Vert er að taka fram að próun fyrirtækja er út frá svörum starfsmanna en ekki pýðinu.

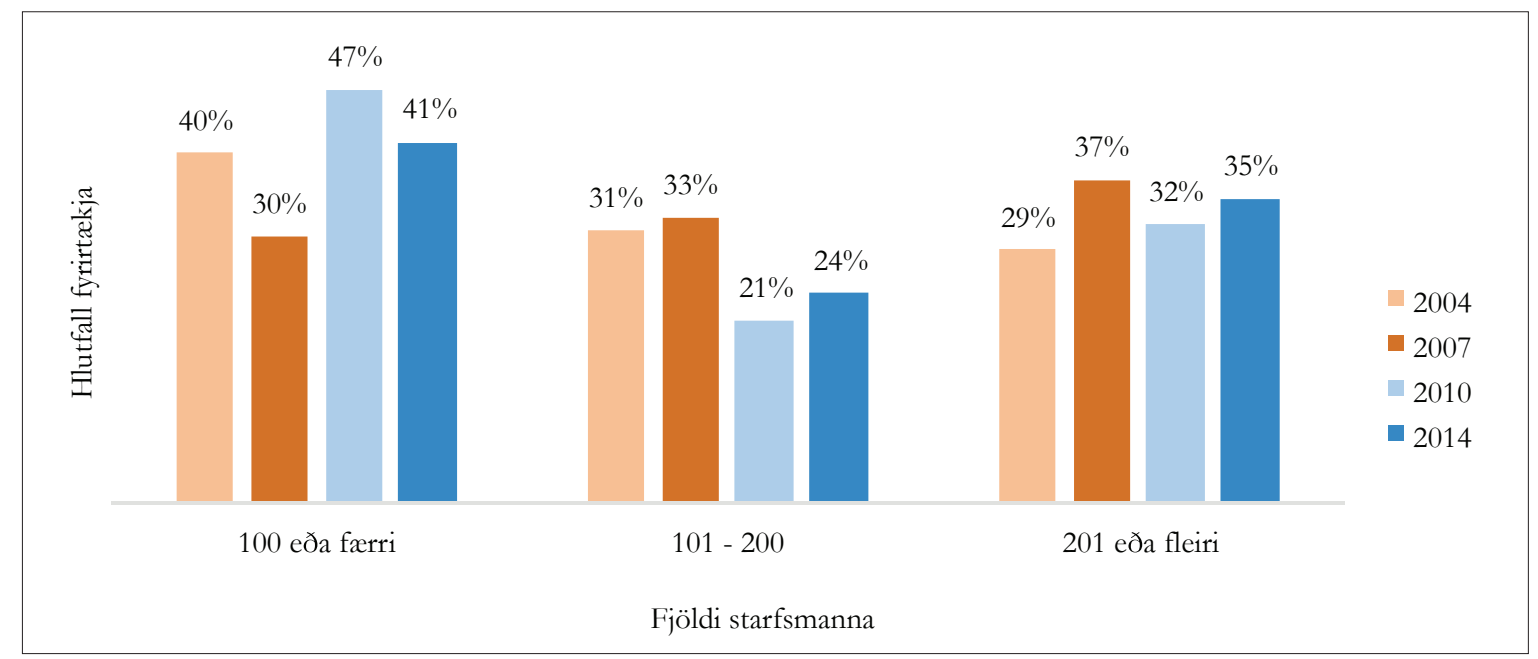

Mynd 1. Próun á stærð fyrirtækja 2004-2014

Heimild: Framsetning byggð á niðurstöðum Innform rannsóknarinnar á Íslandi 2010-2014. 


\subsubsection{Skipulagsbreytingar á Íslandi}

Pegar niðurstöður skipulagsbreytinga Innform könnunarinnar eru skoðaðar verður að hafa í huga að tímabilið 2004-2014 er mikið tímabil umróts í íslensku atvinnulífi. Mikill vöxtur var í atvinnulífinu á peim tíma sem fyrri Innform könnunin var gerð, á árunum 2004-2007, en aftur á móti tekur seinni Innform könnunin á tímabili eftirhruns áranna 2010-2014. Til að skoða breytingar í skipulagi fyrirtækja var spurt um að hvaða marki formlegt stjórnskipulag fyrirtækisins tók mið af hverju af eftirfarandi atriðum árið 2014 og hvernig pað var árið 2010? Atriðin sem vísað var til og tilgreind í könnuninni voru: Vörur og pjónusta, landsvæði, störf, flétta, verkefni, viðskiptavinir, samstæða sjálfstæðra félaga og eignarhaldsfélög.

Við fyrstu sýn virðast niðurstöður pessarar spurningar sýna tvær sams konar sveiflur, pað er annars vegar milli áranna 2004 og 2010 og hins vegar milli áranna 2007 og 2014. Tvennar ástæður geta legið að baki pessum samskonar sveiflum: Sú fyrri er að petta súlurit gefi góða mynd af hruninu par sem allar 2010-súlurnar fara niður miðað við súlurnar fyrir árið 2007. Svæðisskipulagið er pó undantekning og möguleg skýring á pví er gefin hér á eftir. Seinni ástæðan getur verið að um sálfræðilega skekkju svarenda (stjórnenda) sé að ræða. Svarendur gátu valið á milli fimm svarmöguleika, frá engri áherslu til mikillar áherslu, sem lýstu pví að hve miklu marki stjórnskipulag peirra tæki mið af átta tegundum stjórnskipulags. Hugsanlega hafa stjórnendur ýkt pá pætti sem peir gáfu svar við par sem peim var gefinn kostur á að gefa bara svar við peim páttum sem sneru að peirra stjórnskipulagi og máttu pví skilja aðra pætti eftir án svara. Af peim sökum getur verið um að ræða skekkju pegar heildarsvörun Innform rannsóknarinnar 2014 er dregin saman. Höfundar hallast pó frekar að pví að ástæðan fyrir dýfunni árið 2010 sé fólgin í ytri páttum, pað er hruninu og verða rök færð fyrir pví síðar í pessum kafla.

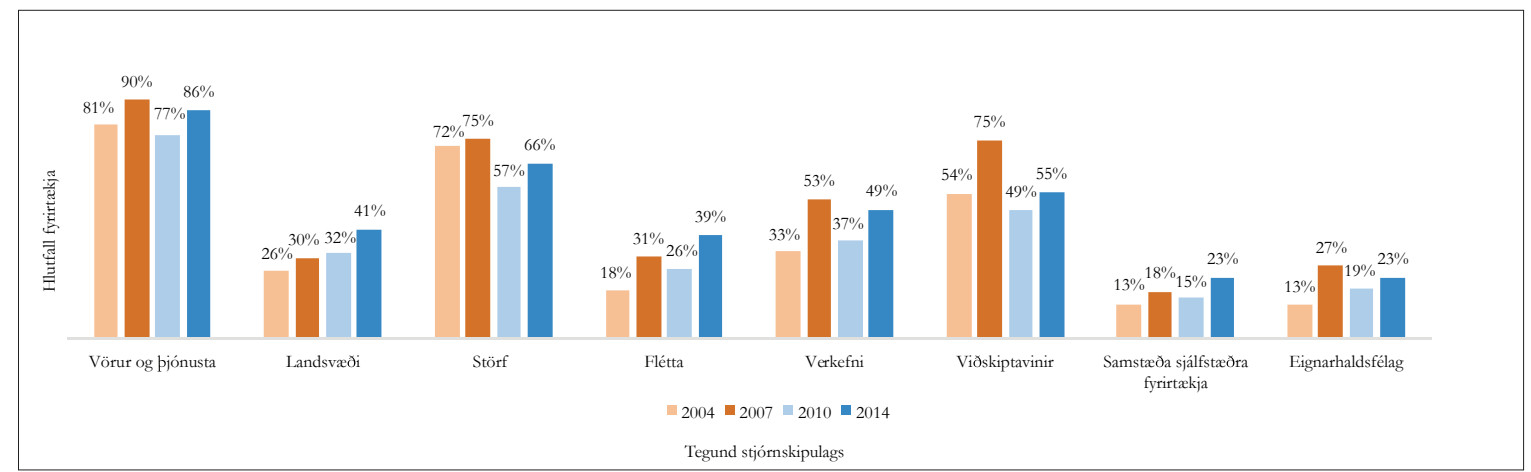

Mynd 2. Breytingar á stjórnskipulagi íslenskra fyrirtækja 2004-2014

Heimild: Framsetning byggð á niðurstöðum Innform rannsóknarinnar á Íslandi 2004-2007 og 2010-2014.

Niðurstöður sýndu að flest íslensku fyrirtækin sem Innform rannsóknin náði til lögðu áherslu á afurðatengt stjórnskipulag sem byggist á vörum og pjónustu og fór pað úr 77\% upp í 86\% á árunum 2010-2014. Óhætt er að segja að pessar niðurstöður bendi sterklega til pess að pessi tegund skipulags, p.e. afurðaskipulagið, hafi verið ráðandi hjá stórum íslenskum fyrirtækjum. Pó má benda á, eins og mynd 2 gefur til kynna, að pegar litið er á öll árin eru sveiflurnar ekki pað miklar að hægt sé að tala um marktækan mun. Mikil áhersla var lögð á viðskiptavininn árið 2007 og hafði pá sú áhersla aukist um 21\% frá pví 2004. Eftir hrunið kom dýfa og áherslan sem hafði verið á viðskiptavininn fór niður í 49\%, sem samsvarar 26\% lækkun, en hún jókst síðan aftur um 6\% árið 2014. Líkleg skýring á pessum sveiflum í afurðaskipulagi (vörur/pjónusta og viðskiptavinurinn) stærri fyrirtækja er að pau hafi horft meira inn á við eftir hrun og lagt meiri áherslu á skilvirkni og hagkvæmni í rekstri með lækkun kostnaðar.

Starfaskipulag hefur verið algengt stjórnskipulagsform hjá íslenskum fyrirtækjum og pví vekur athygli hversu mikið dró úr notkun pess á milli áranna 2007 og 2010 eða um 18\%. Notkun pess jókst svo aftur úr 57\% árið 2010 i 66\% árið 2014 eða um 9\%. 
Fléttu- og verkefnaskipulag eiga pað sammerkt að vera ferlamiðuð en fléttuskipulag próast oft upp úr verkefnaskipulagi, sbr. umfjöllun í kafla 2. Eins og sést á mynd 2 pá sýna niðurstöður fyrir árin 2010-2014 að flétta er ein af tveimur skipulagsgerðum sem fór upp fyrir hlutfallið úr 2007 könnuninni. Á árunum 2010-2014 fór aukning á notkun á fléttuskipulaginu úr 26\% í 39\% en fléttuskipulagið lækkaði aðeins um 5\% á milli áranna 2007-2010. Árið 2007 stóð notkun á verkefnaskipulagi í 53\% en notkunin fór síðan niður í 37\% eftir hrun. Möguleg skýring á pví kann að vera að eftir hrunið hafi dregið úr áherslum á verkefni eða peim hreinlega fækkað miðað við pað sem áður var. Bæði pessi skipulagsform sýna sterka viðleitni fyrirtækja til að efla samræmi, skilvirkni og áherslu á innra starf sem er í góðum takti við tíðarandann eftir hrun. Aukning hafði einnig orðið á notkun eignarhaldsskipulags, bæði á samstæður og eignarhaldsfélög á tímabilinu en ef horft er á allt tímabilið (2004-2014) urðu engar markverðar breytingar, sem er í sjálfu sér athyglisverð niðurstaða í ljósi umrótanna sem voru á pessum árum.

Notkun á svæðisskipulagi jókst öll árin sem um ræðir eða úr 26\% 2004 í 41\% árið 2014. Pessar niðurstöður vekja eftirtekt par sem að baki svæðaskipulags er oftast starfsemi í fleiri löndum sem gefur vísbendingu um erlenda starfsemi fyrirtækja. Útrás getur skýrt aukninguna á árunum fyrir hrun en erfiðara er að daga fram pau rök eftir hrunið. Skýringin á pessu gæti pó verið sú að svarendur skynji markaðssvæði sitt sem Ísland og í pví samhengi sé rökrétt að áhersla á svæði innanlands hafi aukist eftir hrun.

\subsubsection{Breytingar ferla á Íslandi}

Til að kanna breytingar í ferlum íslenskra fyrirtækja var með tvennum hætti spurt út í ákvörðunartöku og umboð stjórnenda undirdeilda. Í fyrri spurningunni var spurt að hvaða marki geta stjórnendur undirdeilda tekið ákvarðanir varðandi starfsemina (t.d. breytt vörum, endurskipulagt framleiðsluferla eða skipt um stærstu birgja)?

Eins og mynd 3 gefur til kynna höfðu stjórnendur mikið umboð til aðgerða varðandi starfsemina í 45\% tilvika árið 2014 en hlutfallið var 33\% árið 2010. Minnst var hlutfallið hjá fyrirtækjum sem veittu stjórnendum undirdeilda fullt umboð eða aðeins 3\% bæði árin sem tímabilið tók til. Hlutfall peirra fyrirtækja sem veittu stjórnendum sínum ekkert umboð hafði minnkað úr 17\% árið 2010 í 12\% árið 2014 og að sama skapi hafði peim fyrirtækjum fækkað sem höfðu gefið stjórnendum nokkuð umboð til aðgerða eða úr 30\% í 22\% árið 2014. Pegar litið er á samanburð á milli Innform rannsóknanna frá 2007 og 2014 sést að umboðsveiting stjórnenda undirdeilda varð algengari eftir pví sem á leið. Eins og mynd 3 sýnir varð um 9\% aukning bæði á jafnri ábyrgð stjórnenda og höfuðstöðva og pví að stjórnendum væri falið mikið umboð til aðgerða á tímabilinu 2004-2014.

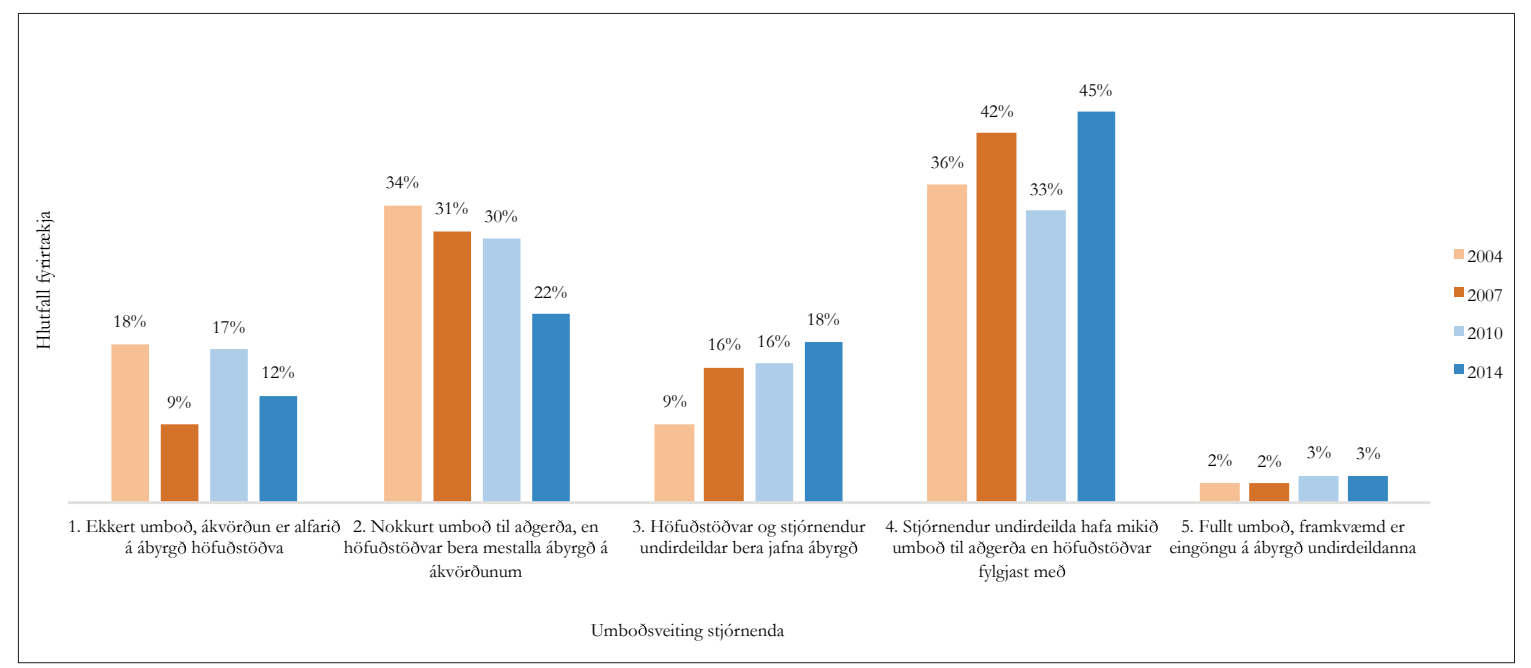

Mynd 3. Umboð stjórnenda undirdeilda til ákvörðunartöku varðandi starfsemina

Heimild: Framsetning byggð á niðurstöðum Innform rannsóknarinnar á Íslandi 2004-2007 og 2010-2014. 
Í seinni spurningunni varðandi ákvarðanatöku stjórnenda undirdeilda var spurt $a$ ðvaða marki hafa undirdeildir umboð til stefnumótandi ákvarðana (t.d. stefnumiðaða áætlanagerð til langs tíma; mat á stórum fjárfestingum)?

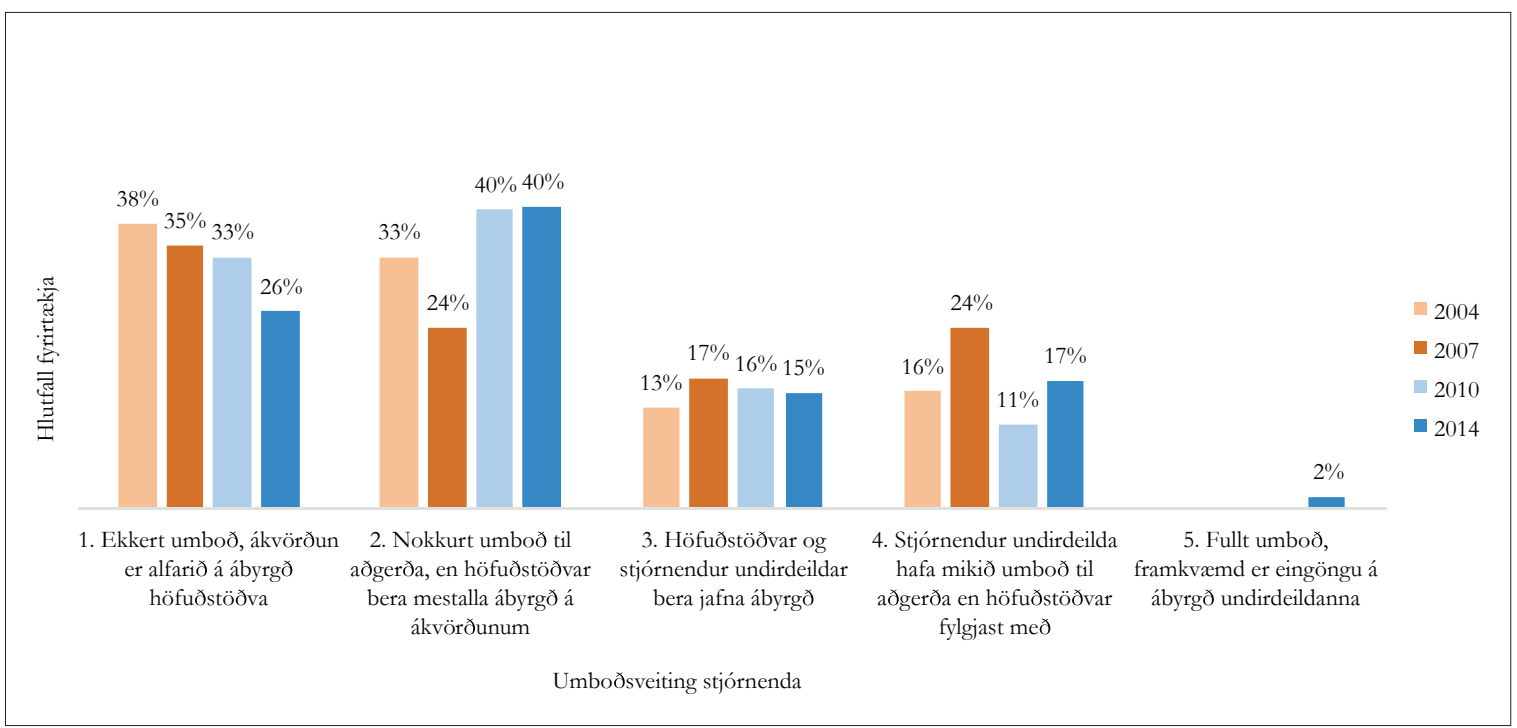

Mynd 4. Umboð stjórnenda undirdeilda til stefnumótandi ákvarðana

Heimild: Framsetning byggð á niðurstöðum Innform rannsóknarinnar á Íslandi 2004-2007 og 2010-2014.

Stjórnendur voru beðnir að tilgreina að hvaða marki stjórnendur undirdeilda hefðu umboð til stefnumótandi ákvarðana í fyrirtækinu. Algengara hafði orðið að stjórnendum undirdeilda væri veitt mikið umboð til stefnumótandi ákvarðana en hlutfallið jókst úr 11\% í 17\% árið 2014. Peim stjórnendum sem fengu ekkert umboð til stefnumótandi ákvarðana hafði fækkað úr 33\% í 26\%. Hlutfall peirra stjórnenda sem höfðu nokkurt umboð varðandi stefnumótandi ákvarðanir stóð í stað á tímabilinu eða í 40\% og að sama skapi sýna niðurstöður að peim stjórnendum sem höfðu jafna ábyrgð á við höfuðstöðvarnar hafði fækkað lítillega eða úr 16\% í 15\% árið 2014. Á árinu 2014 sést að eitt fyrirtæki af peim sem svöruðu spurningakönnuninni hafði veitt stjórnendum undirdeilda sinna fullt umboð til stefnumótandi ákvarðana. Til samanburðar sést að á árunum fyrir hrun veitti rúmlega priðjungur fyrirtækjanna stjórnendum undirdeilda ekkert umboð til stefnumótandi ákvarðana. Í pví ljósi er pó áhugavert að sjá hversu stórt hlutfall fyrirtækja veitti stjórnendum mikið umboð til aðgerða árið 2007 eða $24 \%$.

Pað vakti sérstaka athygli við samanburðinn hér að framan, á milli Innform rannsóknanna (rannsóknar 2 frá 2007 og rannsóknar 4 frá 2015), sú aukning sem orðið hafði hjá fyrirtækjum á notkun fléttu- og verkefnaskipulags á árunum 2010-2014. Pegar litið er nánar á einstaka pætti í töflu 3 pá má sjá jákvæða fylgni, miðað við 99\% öryggismörk, milli umboðsveitingar árið 2014 og fléttuskipulags árið 2014. Einnig er sterk fylgni milli fléttu árið 2014 og láréttra tengsla árið 2014. Viðskiptavinurinn 2014 hefur fylgni við bæði fléttuog verkefnaskipulag árið 2014. Aukinn notkun á aðferðum mannauðsstjórnunar frá árinu 2010 hefur einnig marktæka fylgni við fléttuskipulag 2014. 
Tafla 3. Fylgnimælingar milli ferlatengdra pátta og fléttu- og verkefnaskipulags

\begin{tabular}{|c|c|c|c|c|c|c|c|c|c|c|c|c|}
\hline \multirow[b]{2}{*}{ Áherslupættir í ferlum fyrirtækja } & \multicolumn{3}{|c|}{ Flétta 2014} & \multicolumn{3}{|c|}{ Flétta 2010} & \multicolumn{3}{|c|}{ Verkefni 2014} & \multicolumn{3}{|c|}{ Verkefni 2010} \\
\hline & $r$ & $p$ & $n$ & $r$ & $p$ & $n$ & $r$ & $p$ & $n$ & $r$ & $p$ & $n$ \\
\hline Umboð undirdeilda 2014 & 0,440 & $0.001^{* *}$ & 58 & 0,408 & $0.002^{* *}$ & 55 & 0,258 & $0.041^{*}$ & 63 & 0,195 & 0,131 & 61 \\
\hline Umboð undirdeilda 2010 & 0,320 & $0.016^{*}$ & 56 & 0,398 & $0.003^{* *}$ & 54 & 0,102 & 0,434 & 61 & 0,141 & 0,281 & 60 \\
\hline Viðskiptavinur 2014 & 0,237 & $0.044^{*}$ & 73 & 0,152 & 0,214 & 69 & 0,434 & $0.000^{* *}$ & 79 & 0,492 & $0.000^{* *}$ & 76 \\
\hline Viðskiptavinur 2010 & 0,233 & $0.048^{*}$ & 73 & 0,210 & 0,083 & 69 & 0,336 & $0.002^{* *}$ & 79 & 0,469 & $0.000^{* *}$ & 76 \\
\hline Lárétt tengsl 2014 & 0,374 & $0.003^{* *}$ & 61 & 0,381 & $0.003^{* *}$ & 58 & 0,266 & $0.031^{*}$ & 66 & 0,220 & 0,080 & 64 \\
\hline Lárétt tengsl 2010 & 0,011 & 0,932 & 59 & 0,200 & 0,135 & 57 & 0,077 & 0,548 & 64 & 0,183 & 0,152 & 63 \\
\hline Upplýsingastjórnun 2014 & 0,173 & 0,178 & 62 & 0,147 & 0,267 & 59 & 0,195 & 0,113 & 67 & 0,253 & $0.042 *$ & 65 \\
\hline Upplýsingastjórnun 2010 & $-0,028$ & 0,828 & 61 & 0,152 & 0,250 & 59 & 0,130 & 0,297 & 66 & 0,259 & $0.037^{*}$ & 65 \\
\hline Aðferðir mannauðsstjórnunar 2014 & 0,097 & 0,462 & 60 & 0,131 & 0,330 & 57 & 0,096 & 0,441 & 66 & 0,254 & $0.042^{*}$ & 64 \\
\hline $\begin{array}{l}\text { Aukning á notkun aðferða } \\
\text { mannauðsstjórnunar frá } 2010\end{array}$ & 0,340 & $0.010^{*}$ & 56 & 0,281 & $0.040^{*}$ & 54 & 0,090 & 0,490 & 61 & 0,064 & 0,627 & 60 \\
\hline
\end{tabular}

Heimild: Framsetning byggð á niðurstöðum Innform rannsóknarinnar á Íslandi 2010-2014

Hins vegar reyndist ekki vera marktæk fylgni milli fléttuskipulags (árin 2014 og 2010) og upplýsingastjórnunar (árin 2014 og 2010) og eru pað athyglisverðar niðurstöður í ljósi pess hve flókið fléttuskipulagið getur orðið og að fyrirtæki purfi að búi yfir góðum og réttum upplýsingum á hverjum tíma.

\section{Umræður og frekari rannsóknir}

Niðurstöður Innform rannsóknarinnar sem fjallað er um hér að framan gefa mynd af stöðu stærri íslenskra fyrirtækja hvað stjórnskipulag varðar yfir tímabilið 2004 - 2014, en pessi tími nær til áranna fyrir hrun íslenska fjármálakerfisins, árin sem hrunið stóð yfir og síðan fyrstu árin eftir hrunið. Раð er mat greinarhöfunda að sjá megi viðbrögð fyrirtækja við hruninu í niðurstöðunum hvað stjórnskipulag varðar. Innform rannsóknin sýnir fram á athyglisverðar breytingar á skipulagi og stefnumiðaðri stjórnun íslenskra fyrirtækja fyrir og eftir hrun. Niðurstöðurnar eru pví mikilvægt framlag til pekkingar á próun á stjórnskipulagi íslenskra fyrirtækja sem hjálpar til við að draga upp fyllri mynd af próuninni og styðja við niðurstöður úr öðrum rannsóknum. Að mati höfunda endurspeglast hrunið í niðurstöðum rannsóknarinnar og hve mikil áhrif niðursveiflan í samfélaginu hafði á stjórnunar- og skipulagspætti fyrirtækja.

Fyrirtækin virðast hafa horft fremur inn á við eftir hrunið og sést pað einna skýrast á pví hve mikið dró úr áherslunni á viðskiptavininn í stjórnskipulagi peirra árið 2010. Niðurstöðurnar sýna á hinn bóginn að marktæk tengsl voru milli fléttu- og verkefnaskipulags og viðskiptavinarins fyrir árið 2014 sem gefur vísbendingu um að fyrirtækin hafi verið farin að horfa meira út á við og taka mið af viðskiptavininum í skipulagi sínu árið 2014. Einnig var athyglisvert að mikil fylgni var á milli fléttu- og verkefnaskipulags og umboðsveitingar undirdeilda en innan beggja pessara skipulagsgerða er umboðsveiting til undirdeilda mikilvæg (Anna Marín Pórarinsdóttir, 2017).

Рað vekur jafnframt athygli að áhersla á að kynna formlega stefnu hjá íslenskum fyrirtækjum virðist hafa minnkað töluvert eftir hrun en pá lagði aðeins helmingur fyrirtækja áherslu á að kynna meginhlutverk og -gildi fyrir starfsmönnum sínum (Anna Marín Pórarinsdóttir, 2017). Petta er breyting frá Innform 2007 pegar um 70\% fyrirtækja sýndu fram á formlega stefnu (Einar Svansson og Runólfur Smári Steinpórsson, 2012). Mögulega er hægt að færa fyrir pví rök að sú niðursveifla sem varð á viðskiptalífinu eftir hrun skýri af hverju fyrirtæki hafi ekki lagt meiri áherslu á að kynna megingildi og -hlutverk fyrir starfsmönnum, pað er að fyrirtækin hafi í raun ekki verið búin að endurmóta og fastsetja stefnuna í eins miklum mæli. Með öðrum orðum að fyrirtækin hafi verið í millibilsástandi. Рað er athyglisvert í pessu samhengi að stjórnskipulag fyrirtækja tók líka tals- 
verðum breytingum á pví tímabili sem rannsóknin tók til. Má með réttu kalla pá breytingu dýfu niður á við sem sjá má vel á niðurstöðunum í mynd 2 í kaflanum hér að framan. Par virðist áhersla á allar tegundir formlegs skipulags minnka eftir hrun. Samantekið virðist pví vera ótvíræð vísbending um pað í niðurstöðunum að íslensk fyrirtæki hafi verið í millibilsástandi fyrstu árin eftir hrunið par sem pau halda að sér höndum varðandi stefnumótun og skipulag.

Ef litið er til hinna íslensku rannsóknanna sem hafa verið reifaðar í greininni, sjá kafla 4, og niðurstöður peirra settar í samhengi við niðurstöður Innform rannsóknarinnar má segja í heildina að niðurstöðurnar séu að miklu leyti í innbyrðis samræmi, en pó ber að hafa í huga að stærð fyrirtækjanna er ekki sú sama í rannsóknunum. Í Innform rannsóknunum (p.e. rannsóknum nr. 2 og 4, sbr. töflu 2 í kafla 4), eru fyrirtækin stærri og pví er skipulag peirra flóknara og fjölbreyttara og par koma fram ýmsar tegundir skipulags sem einkenna stærri fyrirtæki. Samkvæmt Innform rannsókninni fer mest fyrir afurðaskipulagi ásamt verkefna- og fléttuskipulagi, en notkun starfaskipulagsins er samt áfram umtalsverð. Í rannsóknum Inga Rúnars Eðvarðssonar og samstarfsaðila (p.e. rannsóknir nr. 1, 3 og 5 í töflu 2 í kafla 4) eru fyrirtækin hinsvegar smærri og par kemur fram að starfaskipulag er ráðandi form, en stærri fyrirtækin sýna einkenni flóknara skipulags. Stærð fyrirtækja hefur pví áhrif á stjórnskipulag íslenskra fyrirtækja.

Раð er athyglisvert að sjá má aukningu á fléttu- og verkefnaskipulagi í Innform niðurstöðunum frá 2004-2014. Einnig er fléttuskipulagið að koma skýrt fram hjá stærri fyrirtækjunum í öðrum rannsóknum. Einnig má sjá að blandað skipulag er áberandi í Innform niðurstöðunum par sem ýmsar gerðir afurðaskipulags eru ríkjandi í bland við starfaskipulag. Рað má benda á að ekki er spurt beinlínis um blandað skipulag í rannsóknunum á stjórnskipulagi íslenskra fyrirtækja og pað hefur heldur ekki verið kannað til hlítar hvort pað geti verið að pað sem skilgreina má sem blandað skipulag (Runólfur Smári Steinpórsson o. fl., 1995) sé í raun að mælast sem fléttuskipulag í peim rannsóknum sem gerðar hafa verið. Í heildina má segja að starfaskipulag sé ríkjandi hjá smærri íslenskum fyrirtækjum og mögulega er stuðst við blandað skipulag hjá peim stærri par sem afurðaskipulag er áberandi samhliða starfaskipulagi. Jafnframt má sjá vaxandi áherslu á verkefnamiðað skipulag. Sú mynd af skipulagi íslenskra fyrirtækja sem sjá má í rannsóknum hérlendis virðist vera í góðu samræmi við erlendar rannsóknir og almenna pekkingu um skipulag og áhrifapætti pess, sbr. pá umfjöllun um stöðu pekkingar á skipulagi fyrirtækja sem er í greininni.

Eins og vikið var að í inngangi pá eru rannsóknir á skipulagi fyrirtækja almennt séð af skornum skammti og pær lykilheimildir sem stuðst er við um skipulag fyrirtækja eru gamlar (Worren, 2012). Alpjóðlega Innform rannsóknin var sett af stað til pess að bæta úr pessu (Pettigrew o.fl., 2003) og í framhaldi af peim rannsóknum eru nú uppi nýir straumar og áherslur pegar kemur að skipulagi fyrirtækja og rannsóknum á peim (Birkinshaw og Gibson, 2004; Tushman og O'Reilly, 2013). Miðað við hvað er vitað um stjórnskipulag fyrirtækja á Íslandi og hver staðan er erlendis pá er ótvírætt að pörf er fyrir frekari rannsóknir til að sýna fram á með enn skýrari hætti hvernig skipulag fyrirtækja er að próast.

Í samræmi við pað var lagt upp með pað í byrjun að Innform rannsóknin á Íslandi yrði langtímaverkefni. Rannsóknirnar tvær sem gerðar hafa verið hafa náð til eins konar „öfgatímabila“ í íslensku viðskiptalífi, pað er pensluskeiðsins á árunum 2004-2007 og samdráttarskeiðsins á árunum 2010-2014. Með pessari grein og par með víðtækari kynningu á niðurstöðum Innform rannsóknarinnar frá árinu 2014 hafa tvær fyrirlagnir Innform rannsóknarinnar á Íslandi verið lagðar fram á ritrýndum vettvangi. Eins og bent var á í kynningunni á Innform rannsókninni á Íslandi, sbr. inngang og í umfjöllun um stöðu pekkingar í kafla 2, pá hafa bæði rannsóknir og niðurstöður Innform rannsóknarinnar á Íslandi farið fram í hlutum. Heildarniðurstöður Innform rannsóknanna hérlendis hafa ekki verið birtar. Til að mynda lagði (Einar Svansson, 2008a) í sinni MS ritgerð áherslu á pætti sem snéru að alpjóðavæðingu út frá niðurstöðum Innform rannsóknarinnar 2007 enda náði tímabil 
peirrar rannsóknar til pensluáranna. Bergdís Björk Sigurjónsdóttir (2009) vann með upplýsingar um mannauðsmál á grundvelli Innform rannsóknarinnar sem gerð var 2007 og Pórhildur Guðsteinsdóttir vék sömuleiðis að niðurstöðum um nýsköpun (2009). Áherslan í MS ritgerð Önnu Marínar Pórarinsdóttur (2017) var hinsvegar auk skipulagspátta á að tengja Innform rannsóknina við hugmyndir um gæðastjórnun.

Fróðlegt væri pví að gera nánari grein fyrir heildarniðurstöðum beggja Innform rannsóknanna (2007 og 2014) og sýna út frá fleiri gögnum hvernig tíðarandinn endurspeglast í fleiri páttum en fyrst og fremst stjórnskipulagi fyrirtækja. Í tengslum við pessar tvær rannsóknir liggja jafnframt fyrir rannsóknir á premur raundæmum e. (case studies) um fyrirtækin Actavis, Bakkavör og Arion banka sem parft væri að gera frekari skil.

Markmiðið er að halda áfram með Innform rannsóknina og leggja spurningakönnunina aftur fyrir stjórnendur á næstu misserum. Jafnframt að víkka rannsóknina meira og taka mið af peim nýju rannsóknaráherslum sem hafa verið að koma fram, sbr. umfjöllunina í kafla 3 varðandi kvika færni og jafnvígar áherslur í skipulagi fyrirtækja um leið og pær niðurstöður myndu verða rýndar með hliðsjón af alpjóðlegum niðurstöðum um bæði pversagnir í skipulagi og mikilvægi pess að leggja áherslu á tvenndir í skipulagi og stjórnun fyrirtækja (Pettigrew o.fl. 2003). Einnig væri áhugavert að gera fleiri raundæmisrannsóknir á próun stjórnskipulags til pess að dýpka enn frekar skilning á ýmsum mikilvægum páttum í skipulagi fyrirtækja á Íslandi.

Rétt er að hafa í huga í lokin að samanburður við erlendar rannsóknir er takmörkunum háður. Íslensk fyrirtæki, jafnvel pau 200-300 stærstu sem eru með yfir 50 starfsmenn eru smá í alpjóðlegum samanburði. Ekki síst orkar pað tvímælis ef bornar eru saman innlendar niðurstöður við stærstu erlendu fyrirtækin (upphaflega Innform rannsóknin). Svarhlutfall íslensku rannsóknanna er fyllilega sambærilegt við erlendu Innform rannsóknirnar en fjöldi svara er samt töluvert minni í flestum tilvikum. Ef til vill væri tækifæri í pví að auka áreiðanleika íslensku rannsóknanna sem hér er lýst með pví að útvíkka samanburð við erlendar niðurstöður. Mætti hugsanlega gera pað með endurbættri og einfaldari útgáfu af Innform mælitækinu sem væri lagt fyrir samhliða á Íslandi og í sambærilegum löndum. Væri par annaðhvort miðað við að finna samanburðarlönd eða landsvæði með svipaðan efnahagslegan bakgrunn eða sambærilega stærð fyrirtækja.

\section{Heimildir}

Armour, H. O. og Teece, D. J. (1978). Organizational structure and economic performance: A test of the multidivisional hypothesis. The Bell Journal of Economics, 9(1), 106-122.

Anna Marín Pórarinsdóttir. (2017). Frá útrás til endurreisnar: Skipulagsbreytingar Kauppings banka /Arion banka 2003-2014 (MS-ritgerð). Háskólinn á Bifröst: Viðskiptafræðideild. Sótt af: http://hdl.handle.net/1946/28414.

Ásta Dís Óladóttir, Ingi Rúnar Eðvarðsson og Guðmundur Kristjánsson. (2016). Skipulagsform íslenskra fyrirtækja í sveiflukenndu viðskiptaumhverfi 2007-2016. Tímarit um viðskipti og efnahagsmál, 13(2), 17-37.

Barney, J. (2001). Resource-based theories of competitive advantage: A ten-year retrospective on the resourcebased view. Journal of Management, 27, 643-650.

Bergdís Björk Sigurjónsdóttir. (2009). Mannauðsstjórnun, pjálfun og starfspróun. Tengsl við framleiðni vinnuafls $i$ íslenskum fyrirtækjum (Óbirt BA ritgerð). Háskóli Íslands, Reykjavík.

Birkinshaw, J. og Gibson, C. (2004). Building ambidexterity into an organization topic: Leadership and organizational studies. Reprint 45408, 4, 47-55.

Burns, T. og Stalker, G. M. (1961). The management of innovation. Oxford: Oxford University Press.

Cepeda, G. og Vera, D. (2007). Dynamic capabilities and operational capabilities: A knowledge management perspective. Journal of Business Research, 60, 426-437.

Chandler, A. D. (1962). Strategy and structure: Chapters in the history of the industrial enterprise. Cambridge Mass: The MIT Press.

Child, J. (1984). Organization: A guide to problems and practice (2. útg.). London: Harper \& Row.

Child, J. (2005). Organization: contemporary principles and practice. Oxford: Blackwell Publishing.

Daft, R. L. (1992). Organization theory and design. St. Paul: West Publishing Company.

Darroch, J. (2005). Knowledge management, innovation and firm performance. Journal of Knowledge Management, 9(3), 101-115.

Douma, H. og Schreuder, H. (2013). Economic approaches to organizations (5. útg.). Harlow, Prentice Hall. 
Einar Svansson. (2008a). Stefnumiðuð stjórnun, árangur og árangursmælikvarðar: Alpjóðavæðing og fyrirmyndir (óbirt MS-ritgerð). Háskóli Íslands, Reykjavík.

Einar Svansson. (2008b). Formleg stefna og árangur: Jákvæð tengsl hjá íslenskum fyrirtækjum. Í Ingjaldur Hannibalsson (ritstj.), Rannsóknir í félagsvísindum, IX. Erindi flutt á rádstefnu í október 2008 (bls. 89-99). Reykjavík: Viðskipta- og hagfræðideild Háskóla Íslands.

Einar Svansson og Runólfur Smári Steinpórsson. (2012). Skipulag íslenskra fyrirtækja 2004-2007. Stjórnmál og stjórnsýsla, 8(2), 515-542.

Eisenhardt, K. M. og Martin, J. A. (2000). Dynamic capabilities: What are they?. Strategic Management Journal, 21, 1105-1121.

Fenton, E. M. og Pettigrew, A.M. (2000). Theoretical perspectives on new forms of organizing. Í A.M. Pettigrew og E.M. Fenton (ritstj.), The innovating organization (bls. 1-46). London: Sage.

Foss, N. J. (2003). Selective intervention and internal hybrids: interpreting and learning from the rise and decline of the spaghetti organisation. Organisational Science, 4, 331-349.

Franko, L. G. (1974). The move toward a multidivisional structure in European organizations, Administrative Science Quarterly, 19(4), 493-506.

Galbraith, J.R. (1977). Organization design. Reading, Mass: Addison-Wesley.

Gibson, C. B. og Birkinshaw, J. (2004). The antecedents, consequences, and mediating role of organizational ambidextirity. Academy of Management Journal, 47(2), 209-226.

Graetz, F. og Smith, A. C. T. (2006). Critical perspectives on the evolution of new forms of organisins. International Journal of Strategic Change Management, 1(1), 127-142.

Hedlund, G. (1994). A model of knowledge management and the N-form corporation. Strategic Management Journal, 15, 73-90.

Hobday, M. (2000). The project-based organisation: An ideal form for managing complex products and systems? Research Policy, 29, 871-893.

Ingi Rúnar Eðvarðsson og Guðmundur Kristján Óskarsson. (2008). Skipulagsform íslenskra fyrirtækja. Bifröst Journal of Social Science, 2(1), 5-26

Ingi Rúnar Eðvarðsson. (2006). Stjórnunaraðferðir og skipulag íslenskra fyrirtækja. Tímarit um viðskipti og efnahagsmál, 4(1), 3-26.

Johnson, G., Whittington, R., Scholes, K., Angwin, D. og Regnér, P. (2014). Exploring strategy: text and cases. Harlow: Prentice Hall.

Jones, G. R. (2001). Organizational theory, design and change. New Jersey: Pearson Education.

Hammer, M. (2001). The agenda: What every business must do to dominate the decade. New York: Crown Business.

Král, P. og Králova, V. (2016). Approaches to changing organizational structure: The effect of drivers and communication. Journal of Business Research, 69, 5169-5174.

Lawrence, P. R. og Lorsch, J. W. (1967). Organization and environment: Managing differentiation and integration. Boston: Division of research, graduate school of business, Harvard University.

Leavitt, H. J. (2005). Top down: Why hierarchies are here to stay and how to manage them more effectively. Boston, MA: Harvard Business School Press.

Lewis, M. W. (2000). Exploring paradox: Toward a more comprehensive guide. Academy of Management Review, 25(4), 760-776.

Lubatkin, M. H., Simsek, Z., Ling, Y. og Veiga, J. F. (2006). Ambidexterity and performance in small to medium-sized firms: The pivotal role of top management team behavioral integration. Journal of Management, 32(5), 646-672.

McAuley, J., Duberly, J. og Johnson, P. (2007). Organization theory: Challenges and perspectives. Harlow, Pearson Education Ltd.

Mihalache, O. R., Jansen, J. J. P., Van den Bosch, F. A. J. og Volberda, H. W. (2014). Top management team shared leadership and organizational ambidexterity: A moderated mediation framework. Strategic Entrepreneurship Journal, 8, 128-148.

Mintzberg, H. (1979). The structuring of organizations. New Jersey: Prentice-Hall.

Mintzberg, H. (1993). Stucture in fives: Designing effective organizations. New Jersey: Prentice Hall International.

March, J. G. og Simon, H .A. (1958). Organizations. New York: Wiley.

March, J. G. (1991). Exploration and exploitation in organizational learning. Organization Science, 2(1), 71-87.

Nadler, D. A. og Tushman, M. L. (1997). Competing by design: The power of organizational architecture. New York: Oxford University Press.

Nahm, A. Y., Vonderembse, M. A. og Koufteros, X. A. (2003). The impact of organisational structure on time-based manufacturing and plant performance. Journal of Operations Management, 21, 281-306.

O’Reilly, C. A. III, og Tushman, M. L. (2004). The ambidextrous organization. Harvard Business Review, 82(4), 74-83.

O'Reilly, C. A. III, og Tushman, M. L. (2008). Ambidexterity as a dynamic capability: Resolving the innovator's dilemma. Research in Organizational Behavior, 28, 185-206.

Pettigrew, A. M., Whittington, R., Melin, L., Sanchez-Runde, C., Van den Bosch, F. A., Ruigrok, W., og Numagami, T. (2003). Innovative forms of organizing: International perspectives. London: Sage.

Pettigrew, A. M. og Fenton, E. M. (2000). The innovating organization. London: Sage. 
Pettigrew, A. M. og Massini, S. (2003). Innovative forms of organizing: Trends in Europe, Japan and the ISA in the 1990s. Í A. M. Pettigrew, R. Whittington, L. Melin, C. Sanchez-Runde, F. A. Van den Bosch, W. Ruigrok og T. Numagami (ritstj.), Innovative forms of organizing: International perspectives (bls. 1-32). London: Sage.

Peters, T. (1992). Liberation management: Necessary disorganization for the nanosecond nineties. New York: Knopf.

Peters, T. (2003). Re-imagine. New York: Dorling Kinderslay Limited.

Porter, M. E. (1985). Competitive advantage: Creating and sustaining superior performance. New York: The Free Press.

Pugh, D. S. (1973). The measurement of organization structures. Does context define form?, Organizational Dynamics, 1(4), 19-34.

Runólfur Smári Steinpórsson, Marteinn P. Arnar og Sigurður A. Jónsson. (1995). Skipulag fyrirtækja. Reykjavík: Framtíðarsýn hf. og Viðskiptafræðistofnun Háskóla Íslands.

Runólfur Smári Steinpórsson. (2008). Innform á Íslandi: Fræðilegt samhengi og fyrirmynd. Í Ingjaldur Hannibalsson (ritstj.), Rannsóknir í félagsvísindum IX (bls. 483-495). Reykjavík: Viðskipta- og hagfræðideild Háskóla Íslands.

Sydow, J., Lindkvist, L. og DeFillippi, R. (2004). Project-based organizations, embeddedness and repositories of knowledge: Editorial. Organization Studies, 25(9), 1475-1489.

Teece, D. og Pisano, G. (1994). The dynamic capabilities of firms: An introduction. Industrial and Corporate Change, 3(3), 537-556.

Teece, D. J., Pisano, G., og Shuen, A. (1997). Dynamic capabilities and strategic management. Strategic Management Journal, 18(7), 509-533.

Teece, D. J. (2007). Explicating dynamic capabilities: The nature and microfoundations of (sustainable) enterprise performance. Strategic Management Journal, 28(13), 1319-1350.

Thompson, J. D. (1967). Organizations in action. New York: McGraw Hill.

Tushman, M. L. og O’Reilly, C. A. III. (1997). Winning through innovation. Boston, MA: Harvard Business School Press.

Tushman, M. L. og O’Reilly, C. A. III. (2013). Organizational ambidexterity: Past, present and future. The Academy of Management Perspectives, 27(4), 324-338.

Volberda, H. W. (1999). Building the flexible firm: How to remain competitive. New York: Oxford University Press.

Wernerfelt, B. (1984). A Resource-based view of the firm. Strategic Management Journal, 5(2), 171-180.

Whittington, R. og Mayer, M. (2000). The European corporation: Strategy, structure, and social science. New York: Oxford University Press.

Whittington, R., Pettigrew, A., Peck, S., Fenton, E., og Conyon, M. (1999). Change and complementarites in the new competitive landscape: A European panel study, 1992-1996. Organization Science, 10(5), 583-600.

Williamson, O. E. (1985). The economic institutions of capitalism. New York: The Free Press.

Winter, S. G. (2002). Understanding dynamic capabilities. Strategic Management Journal, 24, 991-995.

Worren, N. (2012). Organisation design: Re-defining complex systems. Harlow: Pearson.

Yang, B., Watkins, K. E. og Marsick, V. J. (2004). The construct of the learning organization: Dimensions, measurement, and validation. Human Resource Development Quarterly, 15(1), 31-55.

Zahra, S. A., Sapienza, H. J. og Davidsson, P. (2006). Entrepreneurship and dynamic capabilities: A review, model and research agenda. Journal of Management Studies, 43(4), 917-955.

Zheng, W., Yang, B. Og McLean, G. N. (2010). Linking organizational culture, structure, strategy, and organizational effectiveness: Mediating role of knowledge management. Journal of Business Research, 63, 763-771.

Zott, C. (2003). Dynamic capabilities and the emergence of intraindustry differential firm performance: insights from a simulation study. Strategic Management Journal, 24(2), 97-125.

Pórhildur Guðsteinsdóttir. (2009). Nýsköpun og vörupróun (Óbirt meistararitgerð). Háskóli Íslands, Reykjavík. 
